\title{
Operários e operárias da fábrica a vapor de chapéus de Antônio José Maia \& Cia.: gênero, idade, qualificação profissional e nacionalidade. Recife, década de 1880.
}

\author{
Workers of Antônio José Maia \& Cia.'s hat steam factory: gender, age, \\ professional qualification and nationality. Recife, 1880s.
}

\section{Marcelo Mac Cord*}

Resumo: Aberta oficialmente em meados de 1882, a fábrica a vapor de chapéus de Antônio José Maia \& Cia. tinha proprietários portugueses. Eles foram obrigados por lei a contratar uma cota de aprendizes nacionais e garantir sua subsistência. No bojo dessa exigência, havia o problema da "transição" do trabalho escravo para o livre e os históricos conflitos entre nativos e estrangeiros no mercado de trabalho. No início da operação do empreendimento fabril, a maior parte da mão de obra especializada era portuguesa. Aos pernambucanos e às pernambucanas das mais variadas idades, foram destinados, de uma forma geral, os serviços mais simples e provisórios. Entre os anos de 1882 e 1886, os portugueses foram paulatinamente substituídos por nacionais formados na própria fábrica a vapor de chapéus, barateando custos de produção. Naquele mesmo espaço de tempo, meninas, meninos, moças, rapazes e mulheres adultas, brasileiros contratados como aprendizes, foram os que mais sofreram com a precarização e com a rotatividade nas oficinas da chapelaria. Nosso artigo analisa as complexidades do objeto de estudo por meio dos instrumentos da história social do trabalho.

Palavras-chave: chapelaria, fábrica de chapéus, operários, operárias.

Abstract: Officially opened in mid-1882, Antonio José Maia \& Cia.'s steam factory had Portuguese owners. They were required by law to hire a quota of national apprentices and secure their livelihoods. At the heart of this demand was the problem of the "transition" from

Doutor em História pela Universidade Estadual de Campinas (Unicamp). Professor Adjunto de História da Educação da Faculdade de Educação da Universidade Federal Fluminense (UFF). E-mail: marcelomaccord@ gmail.com. ORCID: https://orcid.org/0000-0001-5694-7007. 
slavery to free labour and the historical conflicts between natives and foreigners in the labour market. At the beginning of the operation of the factory work, most of the specialized workforce was Portuguese. Pernambucans men and women of various ages were generally assigned the most simple and provisional services. Between 1882 and 1886, the Portuguese were gradually replaced by nationals, trained at the very hat steam factory, thus making production costs cheaper. In that same period of time, boys, girls, teenagers and adult women, all Brazilians and hired as apprentices, were the ones who suffered the most from precariousness and the high turnover in the headgear workshops. Our article analyses the complexities of the object of study through the instruments of social history of labour.

Keywords: headgear, hat factory, factory workers.

VALDo CABRAL DE Mello afirma que, entre os anos 1873e 1896, Pernambuco experimentou grave depressão econômica. Nos anos 1870, por causa disso, o erário registou a queda de $30 \%$ na arrecadação. O consequente desequilíbrio nas contas públicas não podia encontrar remédio em empréstimos feitos junto ao mercado, pois a legislação imperial impedia que os poderes locais desfrutassem desse tipo de autonomia. Para reequilibrar os balanços financeiros, a saída mais imediata, e não menos conflitiva, era a criação de novos tributos e o aumento das alíquotas dos que existiam. Contudo, em 1882, seguindo em direção oposta, os políticos pernambucanos extinguiram o imposto do consumo, que era a principal fonte da tesouraria provincial. ${ }^{1}$ A ausência dos respectivos recursos causou tantos transtornos que foi preciso buscar compensações. No ano de 1883, por exemplo, foi criado o imposto de repartição, que impunha ao setor produtivo, independentemente de seu porte, o pagamento de novos tributos. ${ }^{2}$ Ensaios sobre a taxação do sal também foram pensados, mas sem sucesso. Em três anos, a dívida provincial crescera 55\%. Em 1885, o estrangulamento das receitas exigiu a reedição do imposto de consumo sob a alcunha "imposto de giro". ${ }^{3}$

Em meio à crise econômico-fiscal e em busca de alternativas, um grupo organizou, em 1885, a participação dos produtores agrícolas pernambucanos na Exposição da Antuérpia. A iniciativa pretendia atrair novos importadores e investidores externos. ${ }^{4}$ No período em quadro, contudo, para além da "vocação agrícola" da província, o Recife esboçava, apesar das dificuldades, contornos fabris. Um periódico de 1886 indicava a presença de diversas manufaturas, fabriquetas e fábricas na cidade: uma de rapé, quatro de picar fumo a vapor, oito de vinagre, quatro de licores e genebras, seis de carroças, uma de velas, uma de fiação de tecidos de algodão, uma de colchões, uma de escovas e vassouras de piaçava, uma de azeite

1 Até aqui, tudo em: MELLO, Evaldo Cabral de. O norte agrário e o Império: 1871-1889. Rio de Janeiro: Topbooks, 1999, p. 256 e 260.

2 MAC CORD, Marcelo. Imperial Sociedade dos Artistas Mecânicos e Liberais: mutualismo, cidadania e a reforma eleitoral de 1881 no Recife. In: MAC CORD, Marcelo; BATALHA, Claudio H. de M. (orgs.). Organizar e proteger: trabalhadores, associações e mutualismo no Brasil (séculos XIX e XX). Campinas: Editora da Unicamp; FAPESP, 2014. p. 177 et seq.

3 MELLO, op. cit., 1999, p. 276-277.

4 SUCCINTA noticia sobre a indústria da província de Pernambuco organisada com o fim de dar algumas informações das riquezas exploráveis e pecuniárias da província pela Comissão Agenciadora de Productos Naturaes para a Exposição da Antuérpia na Bélgica no anno de 1885. Pernambuco: Typographia Apollo, 1885. 
de coco, uma de óleos vegetais, uma de gelo, uma de macarrão, uma de carvão animal, uma de envernizamento de couros, uma de vinhos de caju e abacaxi, duas de limonada gasosa, três de cerveja, quatro de camisas, cinco de sabão, duas de carros de passeio, uma de vidro, uma de piano, órgãos e realejo e uma de chocolate. ${ }^{5} \mathrm{Em}$ pequeno número e pressionadas por impostos e pela estagnação, elas eram insuficientes para empregar os mais pobres, que, devido às conjunturas, tinham imensa dificuldade para arrumar serviços.

As pressões da população recifense por trabalho eram antigas. O Censo de 1872 sugere que a concorrência se intensificou em tempos de desagregação do escravismo, visto que $87,03 \%$ dos moradores da capital pernambucana eram livres e libertos. Do total de 116.671 habitantes, independentemente de sua condição jurídica, a maior parte era parda, preta e cabocla, ou seja, $59,21 \%$. Os brancos, segundo o documento, eram 40,79\%. Contudo, devemos analisar esse dado com muito cuidado. Por mais que, por exemplo, a comunidade portuguesa fosse grande em terras pernambucanas, não havia tanta gente fenotipicamente europeia pelas ruas. A branquitude é muito mais a afirmação de uma condição social do que um dado biológico. Naquelas porcentagens, portanto, podemos aumentar, e muito, o total de gente com a pele escura (em seus mais variados tons), especialmente entre os que sobreviviam com o suor do próprio rosto. ${ }^{6}$ Como afirma Felipe Souza, "o movimento operário em Recife surgiu enquanto ramificação de uma sólida base de experiências fomentadas em um universo associativo essencialmente negro". ${ }^{7}$ Não devemos perder de vista a questão da cor quando observamos a mão de obra nacional que povoa este artigo.

Na década de 1880, o ramo da chapelaria era bastante pequeno na capital pernambucana, contando com algumas lojas que revendiam e reparavam produtos. As mais destacadas estavam concentradas na Praça da Independência, ponto central da importante freguesia de Santo Antônio. ${ }^{8}$ Uma e outra pequenas manufaturas produziam seus próprios chapéus, mas também não deixavam de oferecer serviços de conserto e de revenda. No topo desse segmento estava a fábrica a vapor de Antônio José Maia \& Cia., fundada em 1882. A sua criação, que foi gestada em finais dos anos 1870, esteve cercada de muita expectativa e de muito debate. Para certos elementos das elites letradas e proprietárias, o maquinário que seria introduzido era visto como sinal de "progresso" e a desejada produção em maior escala poderia conquistar mercados vizinhos, aumentar as rendas públicas e empregar muita gente "desocupada" e "vadia". Atento às oportunidades de negócio, o idealizador do empreendimento fabril usou essas ambições ao seu favor, pressionando as autoridades públicas no sentido de conseguir importantes isenções fiscais em tempos de combalidas arrecadações e de fortes tensões sociais.

Com quase cinco anos de funcionamento, a fábrica a vapor de chapéus havia sido advertida pelas autoridades fiscais pernambucanas. Segundo o governo provincial, Antônio

5 ALMANACH administrativo, industrial e commercial da cidade do Recife para 1886. Pernambuco: Livraria e Papelaria Parisiense de Medeiros \& C Editores Proprietários, 1886. p. 439-445.

6 Até aqui, tudo em: MAC CORD, Marcelo. Cor e letramento nos censos: Recife e cercanias, 1872-1890. Revista Z Cultural, Rio de Janeiro, ano XIV, n. 1, 2019.

7 SOUZA, Felipe Azevedo e. A participação política das classes populares em três movimentos, Recife (c. 1880 - c. 1900). Tese (Doutorado em História) - Instituto de Filosofia e Ciências Humanas, Universidade Estadual de Campinas, 2018, p. 141.

8 ALMANAK administrativo, mercantil, industrial e agrícola da província de Pernambuco para o anno bissexto de 1884. Recife: Typographia Mercantil, 1884. p. 201. 
José Maia \& Cia. deixou de cumprir as obrigações que garantiam suas isenções fiscais. Um conjunto de documentos oficiais foi gerado, para que a situação fosse regularizada ou os impostos tão desejados pela tesouraria provincial fossem pagos em tempos de baixas receitas. Daquela coleção, o mais importante deles, para nosso artigo, é um extenso e detalhado relatório com o registro dos 450 operários e operárias que foram admitidos a partir de 2 de janeiro de 1882. Produzidos em 6 de novembro de 1886, os papéis apresentam dados como nome completo, gênero, idade, nacionalidade, filiação, profissão e nível técnico de cada pessoa contratada. Existem campos que permitem saber quem ainda estava empregado naquela última data. Por fim, outro traz informações extras. Advertimos que existem pequenos erros de escrituração nas 29 páginas do relatório, que necessitamos filtrar e corrigir. Esses ajustes, sublinhamos, não prejudicaram sua integridade. No cruzamento dessa com outras fontes, construímos o exercício interpretativo que se segue.

\section{O surgimento da fábrica a vapor de chapéus de Antônio José Maia \& Cia.}

Nos PRIMEIRos MESES DE 1876, Antônio da Costa Oliveira Maia fez um pedido aos deputados provinciais pernambucanos. Ele solicitou o "privilégio de 20 anos para montar uma fábrica a vapor de chapéus e bem assim isenção de impostos". ${ }^{9}$ Em parte da documentação da Junta Comercial da Cidade do Recife, produzida no alvorecer do ano de 1877, observamos que o peticionário era cidadão português e estava ocupado com o mundo dos negócios. Aos 2 de janeiro, junto com mais dois sócios (um era seu compatriota e o outro brasileiro), o trio firmou contrato para a abertura de um estabelecimento dedicado à "compra e venda de secos e molhados tanto a grosso como a varejo". ${ }^{10}$ Não era mera coincidência o envolvimento de Antônio da Costa Oliveira Maia com esse tipo de negócio. Segundo Bruno Augusto Dornelas Câmara, os portugueses dominavam "o mercado de víveres da chamada 'carne seca', vendida a retalho nos armazéns de secos e molhados" da capital pernambucana. ${ }^{11}$ Em outro texto, o mesmo historiador demonstrou como esse tipo de monopólio comercial gerou profundos conflitos entre lusitanos e pernambucanos, que chegaram muitas vezes às vias de fato em meados do século XIX. ${ }^{12}$

Bastante provável é que Antônio da Costa Oliveira Maia possuísse mais casas de secos e molhados espalhadas pelo Recife e quisesse diversificar sua atuação em outro lucrativo negócio. No século XIX, chapéus de todos os tipos eram usados pelas classes sociais como símbolos de identidade e de distinção. ${ }^{13}$ No Recife da década de 1870 , algumas lojas, além

9 Diário de Pernambuco, Recife, 23 mar. 1876. Disponível em: http://memoria.bn.br/hdb/periodico.aspx. Acesso em: 15 ago. 2019.

10 Até aqui, tudo em: Contrato n. 63, Índice dos contractos e distractos de sociedades commerciais archivados em 1877, Secretaria da Junta Commercial da Cidade do Recife, Junta Comercial de Pernambuco (doravante JUCEPE), Fundo: Junta Comercial de Pernambuco; natureza: manuscrito.

11 CÂMARA, Bruno Augusto Dornelas. O "retalho" do comércio: a política partidária, a comunidade portuguesa e a nacionalização do comércio a retalho, Pernambuco 1830/1870. Recife: Editora Universitária da UFPE, 2013. p. 271.

12 Idem. Trabalho livre no Brasil Imperial: o caso dos caixeiros de comércio na época da Insurreição Praieira. Dissertação (Mestrado em História Social) - Centro de Filosofia e Ciências Humanas, Universidade Federal de Pernambuco, Recife, 2005.

13 SANTOS, Lyndon de Araújo. Os brácaros chapeleiros: mundos e representações dos chapéus no Rio de 
de importar essa peça indispensável do vestuário masculino e feminino, possuíam oficinas de reparo e manufaturavam seus próprios produtos, como a chapelaria de Antônio José Maia \& Irmão. ${ }^{14}$ "Modernizar" os processos de produção poderia acabar com esse tipo de concorrente e garantir o controle do mercado. Dois outros fatores podem ter colaborado para que o português se animasse com a produção chapeleira de caráter industrial. De forma direta, na Corte, com o advento da mecanização do setor, ocorrido nos anos 1860, empresas como a Fernandes Braga \& Cia., que era propriedade de lusitanos, atingiram enorme sucesso comercial. ${ }^{15}$ De forma indireta, os resultados obtidos com as máquinas a vapor na moagem da cana-de-açúcar, a partir dos anos 1870, apontavam para a necessidade da ampliação do "progresso" tecnológico e produtivo para outros setores econômicos. ${ }^{16}$

Outro indício nos alerta para a experiência de Antônio da Costa Oliveira Maia no mundo dos negócios. Ele surge, não por acaso, quando o português solicitou aos deputados pernambucanos privilégio de 20 anos e isenção de impostos para instalar sua fábrica a vapor de chapéus. Parece evidente que o europeu tinha conhecimento da legislação nacional e de nossas práticas político-econômicas. Beatriz Piva Momesso afirma que, no Brasil da primeira metade do século XIX, a Junta de Comércio, Agricultura, Fábricas e Navegação concedia proteção aos indivíduos que inventassem, introduzissem ou melhorassem os mais diversos maquinários. Aqueles que trouxessem para o país novidades produtivas teriam cinco anos de exclusividade sobre seus processos. O prazo subiria para 15 anos quando os solicitantes inventassem e melhorassem produtos. Na lista de possíveis mercês, ainda podemos elencar empréstimos e isenções de direitos para a aquisição de matérias-primas e de equipamentos. ${ }^{17}$ Nesse sentido, e extrapolando para a segunda metade do século XIX, a própria Assembleia Provincial de Pernambuco costumava conceder exclusividades, isenções e outras vantagens para aqueles que inovassem e introduzissem máquinas. ${ }^{18}$

Ainda no primeiro semestre de 1876, a solicitação de Antônio da Costa Oliveira Maia seguiu para debate legislativo, mas o "projeto $n^{\circ} 53$ " não foi apreciado por falta de quórum. ${ }^{19}$ Por motivos que ainda desconhecemos, parece que o papel ficou engavetado por quase um ano. Somente em meados de 1877, após a terceira discussão da matéria, as autoridades pernambucanas aprovaram a criação de "uma fábrica de chapéus de lã, pelo, lebre e castor". ${ }^{20}$ A Lei no 1.289, publicada em 9 de julho, possuía quatro artigos. No primeiro deles, o presidente da província foi autorizado "a contratar com Antônio da Costa Oliveira Maia, ou

Janeiro (1825-1898). Vária História, Belo Horizonte, v. 31. n. 57, p. 788, set.-dez. 2015.

14 Jornal do Recife, Recife, 8 jun. 1877. Disponível em: http://memoria.bn.br/hdb/periodico.aspx. Acesso em: 15 ago. 2019.

15 SANTOS, op. cit., passim.

16 Em Pernambuco, no início dos anos 1870, 6\% dos 440 engenhos empregavam energia a vapor. Nos primeiros anos da década seguinte, 21,5\% dos 609. EISENBERG, Peter. Modernização sem mudança: a indústria açucareira em Pernambuco, 1840-1910. Rio de Janeiro, Paz e Terra; Campinas, Editora da Unicamp, 1977, p. 62.

17 Até aqui, tudo em: MOMESSO, Beatriz Piva. Indústria e trabalho no século XIX: o estabelecimento de fundição e máquinas de Ponta d'Areia. Dissertação (Mestrado em História Social) - Instituto de Ciências Humanas e Filosofia, Universidade Federal de Fluminense, Niterói, 2007. p. 49-50.

18 MAC CORD, Marcelo. Artífices da cidadania: mutualismo, educação e trabalho no Recife oitocentista. Campinas: Editora da Unicamp; FAPESP, 2012. p. 215 et seq.

19 A Província, Recife, 26 mai. 1876. Disponível em: http://memoria.bn.br/hdb/periodico.aspx. Acesso em: 15 ago. 2019.

20 A Província, Recife, 1 mai. 1877. Disponível em: http://memoria.bn.br/hdb/periodico.aspx. Acesso em: 15 ago. 2019 
a quem melhores vantagens oferecer, a construção e exploração de uma fábrica a vapor [...] para fazer chapéus [...] sem prejuízo da pequena indústria existente". No seguinte, o contratante era obrigado a empregar, vestir e sustentar 12 menores brasileiros (na condição de aprendizes) e "explorar a matéria-prima que exista no pais, conveniente ao fabrico". No terceiro, a fábrica, suas dependências, seus produtos e as matérias-primas importadas ficavam isentos de direitos e de impostos provinciais e municipais durante 15 anos. O último artigo revogava as disposições em contrário. ${ }^{21}$

Nesse momento da pesquisa, tendo em vista o teor da Lei $n^{\circ} 1.289$, não temos condições de discutir os meandros legais que viabilizaram sua aprovação, mas neles notamos sobrevivências das antigas práticas da Junta de Comércio da Corte. Prova disso são as diversas isenções tributárias que foram concedidas pelo prazo de 15 anos, por causa da promessa de melhorias na produção de chapéus. De forma perspicaz, o governo pernambucano também entendeu que a abertura da fábrica a vapor era algo de interesse público. Na medida em que o empreendimento poderia movimentar a combalida economia provincial e gerar empregos, era preciso que saísse efetivamente do papel. Prova disso é que o interesse pessoal de Antônio da Costa Oliveira Maia, que solicitou o favor, foi colocado em segundo plano. Outro capitalista mais bem preparado poderia vencer a concorrência. Atenta aos interesses político-econômicos locais, aquela norma ainda esteve preocupada com a sobrevivência das pequenas e médias manufaturas, pois seria muito inoportuno o fechamento de suas portas em época de recessão. Desde os anos 1860, os artífices recifenses também lutavam contra monopólios fabris, temendo por sua sobrevivência. ${ }^{22}$

A contratação de 12 menores brasileiros para a função de aprendiz, e seu sustento, é algo bastante importante na Lei $n^{\circ} 1.289$. Primeiramente porque, pelo menos desde meados do século $\mathrm{XIX}$, os pernambucanos lutavam por sua contratação em oficinas e armazéns dominados por patrões portugueses, que quase sempre os preteriam. ${ }^{23}$ Reservar uma parcela dos empregos para os meninos e para os jovens recifenses parecia ser prudente. Demonstrar interesse em empregar mão de obra nacional poderia evitar sérios conflitos, pois tudo indicava que a futura fábrica a vapor de chapéus seria controlada por um lusitano e, tendencialmente, contaria com muitos de seus patrícios nas funções operárias. Por sua vez, a imposição legal também era fruto da condição social dos menores pernambucanos, em sua maior parte pobre, preta, parda e sem ofício. No transcorrer do século XIX, segundo Irma Rizzini, as elites letradas e proprietárias imperiais entendiam que o emprego dessa gente em "ocupação considerada mais útil [poderia] combater a vagabundagem e a criminalidade”. ${ }^{24}$ Por fim, a importância do artigo $2^{\circ}$ daquela norma vai ao encontro das próprias conjunturas, quando se buscavam soluções para o problema da "transição" do trabalho escravo para o livre.

No início de 1878, havia terminado o prazo para o recebimento das propostas daqueles que queriam montar e gerenciar a fábrica a vapor de chapéus. Somente dois concorrentes

21 Até aqui, tudo em: PERNAMBUCO. Leis provinciaes do anno de 1877. [S. I.: s. n.], 1877. p. 41.

22 MAC CORD, op. cit., p. 215 et seq.

23 CARVALHO, Marcus Joaquim Maciel de. Os nomes da revolução: lideranças populares na Insurreição Praieira, Recife, 1848-1849. Revista Brasileira de História, v. 23, n. 45, p. 209-238, 2003. CÂMARA, 2005, passim. MAC CORD, op. cit., passim.

24 RIZZINI, Irma. Pequenos trabalhadores do Brasil. In: DEL PRIORI, Mary (org.). História das crianças no Brasil. São Paulo: Contexto, 2007. p. 377. 
se interessaram pelo empreendimento. O primeiro deles, obviamente, foi o próprio Antônio da Costa Oliveira Maia. O outro, citado mais acima e conhecedor do ramo, foi Antônio José Maia \& Irmão. ${ }^{25}$ Essa era a razão social da Chapelaria Industrial, que vendia importados, tinha fabricação própria e estava localizada na Rua do Barão da Vitória, n. 36. ${ }^{26}$ Até 1870, o logradouro tinha outro nome, Rua Nova, que era o espaço da elegância e da moda na capital pernambucana. ${ }^{27}$ Isso demonstra a importância do estabelecimento de Antônio e Joaquim José Maia, ambos cidadãos portugueses com vários negócios registrados na Junta Comercial da Cidade do Recife. No início da década de 1880, por exemplo, eles também faziam parte da Constantino, Maia \& Cia., que vendia miudezas e perfumarias, e da Victorino de Abreu \& Cia., que negociava miudezas, quinquilharias e outros artigos. ${ }^{28}$ Apesar de os três envolvidos na concorrência possuírem o mesmo sobrenome, não há pistas de que os irmãos fossem parentes do outro.

O vencedor da concorrência foi Antônio da Costa de Oliveira Maia, mas o presidente da província resolveu cancelar o contrato por inabilitação. O português havia falido um de seus negócios e deixou de quitar as respectivas dívidas. No dia 18 de julho de 1880, por causa disso, as autoridades públicas decidiram que Antônio José Maia \& Irmão tocaria a empreitada. Contudo, 11 artigos deixaram o novo contrato mais detalhado. Foi determinado o prazo de um ano para o início das obras da fábrica a vapor de chapéus e dois para a sua conclusão. Como havíamos analisado, era crucial buscar a breve revitalização da economia pernambucana. Os privilégios industriais e as isenções tributárias do acordo anterior foram mantidos, mas o prazo para seu usufruto foi reduzido para dez anos. Junto disso, foi permitido que Antônio José Maia \& Irmão também negociasse a redução de impostos gerais com o governo central. A necessidade de uso da matéria-prima nacional, em parte da produção, também foi ratificada. Para fins legais, foi definido que o valor da empresa, expressivo, seria de 50:000\$000 Rs. ${ }^{29}$ Comparativamente, Affonso Oliveira \& Cia., destacada empresa recifense de reparo e de venda (em grosso e a retalho) de chapéus, valia 15:000\$000 Rs. ${ }^{30}$

Ainda sobre o acordo feito entre o governo provincial e Antônio José Maia \& Irmão, manteve-se a obrigatoriedade da contratação de 12 menores brasileiros como aprendizes. Como analisamos, algo extremamente importante por causa da "transição" do trabalho escravo para o livre e dos históricos conflitos entre nacionais e portugueses. Havia, contudo, novidade no artigo $3^{\circ}$. Além de vesti-los e sustentá-los, o empregador também deveria medicá-los e remunerá-los tendo como parâmetro o "regulamento dos aprendizes artífices do Arsenal de

25 Diário de Pernambuco, Recife, 23 fev. 1878. Disponível em: http://memoria.bn.br/hdb/periodico.aspx. Acesso em: 15 ago. 2019.

26 Jornal do Recife, 8 jun. 1877. Disponível em: http://memoria.bn.br/hdb/periodico.aspx. Acesso em: 15 ago. 2019.

27 MAC CORD, op. cit., p. 296-297.

28 Até aqui, tudo em: Contrato n. 15, Índice dos contractos e distractos de sociedades commerciais archivados em 1880, Secretaria da Junta Commercial da Cidade do Recife, JUCEPE, Fundo: Junta Comercial de Pernambuco; natureza: manuscrito. Contrato n. 29, Índice dos contractos e distractos de sociedades commerciais archivados em 1882, Secretaria da Junta Commercial da Cidade do Recife, JUCEPE, Fundo: Junta Comercial de Pernambuco; natureza: manuscrito.

29 Diário de Pernambuco, Recife, 12 ago. 1880. Disponível em: http://memoria.bn.br/hdb/periodico.aspx. Acesso em: 15 ago. 2019.

30 Contrato n. 46, Índice dos contractos e distractos de sociedades commerciais archivados em 1881, Secretaria da Junta Commercial da Cidade do Recife, JUCEPE, Fundo: Junta Comercial de Pernambuco; natureza: manuscrito. 
Marinha”. ${ }^{31}$ O Decreto ${ }^{\circ}{ }^{2} 2.615$, de 21 de julho de 1860, reorientou esses espaços militares na Corte, na Bahia e em Pernambuco, determinando que os brasileiros entre 7 e 12 anos, preferencialmente órfãos ou desvalidos, fossem acolhidos pela Companhia de Aprendizes Artífices. Depois de matriculados, os meninos seriam treinados em algum ofício, escolarizados, vestidos, alimentados e medicados. No processo de aprendizagem artesanal, eles também receberiam diárias entre $\$ 100$ Rs e $\$ 300$ Rs, de acordo com o nível de seu aperfeiçoamento. Parte desses valores seriam utilizados para reembolsar os investimentos feitos pelo Estado e para a constituição de poupanças compulsórias. ${ }^{32}$

No dia $1^{\circ}$ de outubro de 1881 , por razões que não conseguimos identificar, uma nova pessoa jurídica foi criada para tocar a fábrica a vapor de chapéus: Antônio José Maia \& Cia. ${ }^{33}$ Contudo, no ano de 1887, uma pista nos ajuda a compreender a mudança, quando foi refeito o contrato. Nessa ocasião, cremos que Joaquim José Maia estivesse morto, pois foi substituído por seu filho brasileiro, Joaquim José Maia Júnior. Antônio José Maia continuava no negócio com quase $18 \%$ do capital aplicado. Havia um terceiro sócio, o português José Joaquim Alves, que detinha, aproximadamente, $73 \%{ }^{34}$ Isso provavelmente explique a mudança de razão social ocorrida no início da década, pois, para que o empreendimento fosse em frente, era preciso somar forças com patrícios muito bem aquinhoados. De fato, José Joaquim Alves movimentou muito dinheiro na praça do Recife. Entre 1877 e 1881, encontramo-lo celebrando e dissolvendo cinco sociedades. Chama atenção sua presença em duas empresas. A primeira delas negociava gêneros de estiva e contava com capital de 41:000\$000 Rs, sendo quase 73\% por ele investido. A outra comprava e vendia fazendas e valia 33:000\$000 Rs. O português injetou aproximadamente $90 \%$ desse montante. ${ }^{35}$

Respeitados os prazos contratuais, era chegada a hora da inauguração da fábrica a vapor de chapéus, instalada na Rua do Visconde de Goiana, n. 147. No Diário de Pernambuco, em sua edição de 29 de junho de 1882, Antônio José Maia informava sobre os festejos que ocorreriam na abertura de seu novo negócio, no dia 3 de julho. Entre 11 e 14 horas, haveria uma comemoração mais restrita, que contaria com a presença do presidente da província e demais convidados. Em seguida, entre 15 e 18 horas, as portas do estabelecimento estariam abertas para a visita do grande público. ${ }^{36}$ No dia 4 , aquele mesmo periódico contou para seus

31 Diário de Pernambuco, Recife, 12 ago. 1880. Disponível em: http://memoria.bn.br/hdb/periodico.aspx. Acesso em: 15 ago. 2019.

32 BRASIL. Decreto ${ }^{\circ}{ }^{2}$.615, de 21 de julho de 1860. Manda observar novo regulamento para as Companhias de Aprendizes Artífices dos Arsenais de Marinha da Corte e províncias da Bahia e Pernambuco. Disponível em: https://www2.camara.leg.br/legin/fed/decret/1824-1899/decreto-2615-21-julho-1860-556578-norma-pe. html. Acesso em: 5 out. 2019.

33 Diário de Pernambuco, Recife, 13 out. 1881. Disponível em: http://memoria.bn.br/hdb/periodico.aspx. Acesso em: 15 ago. 2019.

34 Contrato n. 101, Sociedades commerciais registradas no ano de 1887, Secretaria da Junta Commercial da Cidade do Recife, JUCEPE, Fundo: Junta Comercial de Pernambuco; natureza: manuscrito.

35 Até aqui, tudo em: Contrato n. 115, Índice dos contractos e distractos de sociedades commerciais archivados em 1877, Secretaria da Junta Commercial da Cidade do Recife, JUCEPE, Fundo: Junta Comercial de Pernambuco; natureza: manuscrito. Contrato n. 29, Índice dos contractos e distractos do anno de 1878, Secretaria da Junta Commercial da Cidade do Recife, JUCEPE, Fundo: Junta Comercial de Pernambuco; natureza: manuscrito. Contratos n. 21 e n. 74, Índice dos contractos e distractos de sociedades commerciais archivados em 1880, Secretaria da Junta Commercial da Cidade do Recife, JUCEPE, Fundo: Junta Comercial de Pernambuco; natureza: manuscrito. Contrato n. 62, Índice dos contractos e distractos de sociedades commerciais archivados em 1881, Secretaria da Junta Commercial da Cidade do Recife, JUCEPE, Fundo: Junta Comercial de Pernambuco; natureza: manuscrito.

36 Diário de Pernambuco, Recife, 29 jun. 1882. Disponível em: http://memoria.bn.br/hdb/periodico.aspx. Acesso 
leitores como havia sido a parte mais glamorosa do evento ocorrido na véspera. Segundo o articulista, a inauguração ocorreu em "espaçoso prédio" que estava "garbosamente ataviado com bandeiras e flores". A maior autoridade pernambucana se fez presente, junto com outros ilustres cidadãos. Todos puderam se divertir com a "banda de música" e as "muitas girândolas de foguetes". O motor foi ligado às 11:30h e percebeu-se que "todo o maquinismo é moderno e aperfeiçoado". Às $13 \mathrm{~h}$ "foi servido aos convidados um lauto lunch para 80 talheres, no correr do qual foram trocados muitos brindes". ${ }^{37}$

$\mathrm{Na}$ rica e pomposa festividade, as máquinas em funcionamento impressionaram a todos. Os portugueses que eram donos da fábrica a vapor de chapéus investiram pesadamente no maquinário preciso e estiveram preocupados em importá-lo de seu país natal. Caldeira, motor e peças em geral chegaram a bordo do navio Saint Martin. ${ }^{38} \mathrm{Na}$ reportagem do dia 4 de julho, publicada pelo Diário de Pernambuco, também somos informados de que tudo foi produzido na cidade do Porto "pela Fundição do Ouro de propriedade dos srs. L. F. Souza Cruz \& Filhos". ${ }^{39}$ Francisco Queiroz afirma que essa indústria, fundada por Luiz Ferreira de Souza Cruz no início dos anos 1860, conquistou muitos prêmios e contava com 145 operários em 1880. Ainda segundo o pesquisador, aquela cidade europeia foi bastante conhecida por possuir muitas fundições no século XIX.40 Não bastasse isso, como afirma José Ramada, o Porto tinha larga expertise na indústria chapeleira, ${ }^{41}$ o que garantia aos seus fundidores experiência e conhecimento suficientes para produzir excelentes máquinas para aquele primeiro setor econômico. Parece evidente que nosso estudo de caso reforça a existência de uma forte rede entre os portugueses que viviam aquém e além-mar. ${ }^{42}$

\section{Os operários e as operárias da fábrica a vapor de chapéus em 3 de julho de 1882.}

A REPORTAGEM SOBRE A INAUGURAÇÃo da fábrica a vapor de chapéus trouxe outro importante dado. Segundo o articulista, o estabelecimento tinha "cerca de 80 operários, quase todos nacionais". ${ }^{43}$ Esse informe nos remete para duas questões importantes. A primeira delas reforça as históricas tensões entre brasileiros e portugueses no mundo do trabalho pernambucano.

em: 16 ago. 2019.

37 Até aqui, tudo em: Diário de Pernambuco, Recife, 4 jul. 1882. Disponível em: http://memoria.bn.br/hdb/ periodico.aspx. Acesso em: 16 ago. 2019.

38 Gazeta de Notícias, Rio de Janeiro, 29 set. 1881. Disponível em: http://memoria.bn.br/hdb/periodico.aspx. Acesso em: 1 out. 2019.

39 Diário de Pernambuco, Recife, 4 jul. 1882. Disponível em: http://memoria.bn.br/hdb/periodico.aspx. Acesso em: 16 ago. 2019.

40 QUEIROZ, Francisco. Subsídios para a história das fábricas de fundição do Porto no século XIX. Associação Cultural Amigos do Porto, $3^{a}$ série, n. 19, p. 165-169, 2001.

41 RAMADA, José Antônio Real Pereira. A indústria chapeleira portuense: um exemplo esquecido de patrimônio cultural. População e sociedade, n. 3, p. 273, 1997.

42 Para saber mais sobre as redes entre os portugueses de aquém e além-mar, entre outros, consultar: ALVES, Jorge Fernandes. Os "brasileiros": emigração e retorno no Porto oitocentista. Porto: Faculdade de Letras da UP, 1993. KLEIN, Herbert S. A integração social e econômica dos imigrantes portugueses no Brasil nos finais do século XIX e no século XX. Análise social, v. XXVIII, n. 121, p. 235-265, $1993\left(2^{\circ}\right)$. RIBEIRO, Gladys Sabina. A liberdade em construção: identidade nacional e conflitos antilusitanos no Primeiro Reinado. Rio de Janeiro: Relume Dumará; FAPERJ, 2002. CÂMARA, 2013.

43 Até aqui, tudo em: Diário de Pernambuco, Recife, 4 jul. 1882. Disponível em: http://memoria.bn.br/hdb/ periodico.aspx. Acesso em: 16 ago. 2019. 
Caso elas tivessem abrandado, não se destacaria o fato de que a maior parte dos operários era gente nativa. Como dissemos, aumentar sua empregabilidade, no período em quadro, era uma tentativa de amainar conflitos sociais. A outra questão tem a ver com as dimensões do negócio de Antônio José Maia \& Cia., que, de forma absoluta, pode ser considerado de médio porte. A Fábrica Apolo, que produzia fumo, era uma das maiores do Recife. Em 1885, ela ocupava "cerca de 20 mil metros quadrados com trilhos de ferros para a condução dos produtos que se trazem dos armazéns" e empregava "240 operários, quase todos nacionais" - como vimos, anúncio necessário e recorrente. Junto disso, a Fábrica Apolo possuía maquinário para "picar e desfiar fumo e para estufar" e "extrair óleos vegetais". Para embalar seus produtos, o complexo fabril contava com tipografia, serraria e funilaria. ${ }^{44}$

Podemos desdobrar a segunda questão e realizar comparativos com os próprios concorrentes de Antônio José Maia \& Cia. Em outro momento, demonstramos que essa empresa valia 50:000\$000 Rs e Affonso Oliveira \& Cia. 15:000\$000 Rs. Na primeira metade dos anos 1880, o Recife ainda contava com Carvalho e Irmão \& Cia. e Augusto Fernandez \& Cia.; Antônio Gonçalves de Barros, Antônio da Silva Maia e Francisco Joaquim Pimentel Primo fechavam o rol de competidores. ${ }^{45} \mathrm{~A}$ documentação compulsada não permite saber quantos empregados todos esses estabelecimentos possuíam. Contudo, tendo como base o Censo de 1872, é possível fazer um interessante exercício interpretativo. Nessa primeira grande estatística nacional, quando analisamos os dados das quatro mais importantes freguesias recifenses (São Frei Pedro Gonçalves, Santo Antônio, São José e Boa Vista), observamos que suas chapelarias empregavam 113 operários. Desses, todos livres, temos 28 estrangeiros, 64 brasileiros e 21 brasileiras. ${ }^{46}$ Além da maior presença do trabalhador nacional no mercado de trabalho chapeleiro no início dos anos 1870, inferimos que Antônio José Maia \& Cia. era um gigante em seu setor, com seus quase 80 operários.

Dentre os mais ou menos 80 operários e operárias presentes no dia da inauguração oficial da fábrica a vapor de chapéus, as fontes indicam que os primeiros empregados foram contratados em 2 de janeiro de 1882, quando provavelmente iniciaram a produção. Nessa data, 20 pessoas foram registradas nos livros de Antônio José Maia \& Cia. Podemos afirmar que, no dia 3 de julho, aproximadamente $25 \%$ da força de trabalho fora contratada no início das operações fabris. Desse total, 16 trabalhadores eram portugueses adultos com mão de obra qualificada: dois mestres (um de fula e outro de apropriagem), um oficial arcador e 13 oficiais de fula. Por sua vez, duas portuguesas, com as mesmas características de seus colegas, eram afinadeiras. Os 18 imigrantes poderiam ter vindo do Porto, trazidos pelos próprios patrões sob as leis de locação de serviços, já que essa cidade era um importante centro chapeleiro e origem de todo o maquinário que seguiu para o Recife. Os outros dois que completavam a lista eram rapazes brasileiros, contratados como menores aprendizes: um de fula e outro de apropriagem. Inscritos na documentação como internos, eles teriam direito aos auxílios previstos pela Lei $n^{\circ} 1.289 .{ }^{47}$

44 Até aqui, tudo em: SUCCINTA noticia sobre a indústria da província de Pernambuco: organisada com o fim de dar algumas informações das riquezas exploráveis e pecuniárias da província pela Commissão Agenciadora de produtos naturaes para a Exposição da Antuérpia na Bélgica no anno de 1885. Pernambuco: Typographia Apollo, 1885, p. 35.

45 ALMANAK, op. cit., p. 201.

46 BRASIL. Recenseamento do Brasil em 1872: Pernambuco. Rio de Janeiro: Typographia G. Leuzinger, [1874?]. p. 3, 6, 9 e 12.

47 Até aqui, tudo em: Maço “Impostos, Recife, 1886, Ant ${ }^{\circ} J^{\text {J }}$ Maia \& Cia”, Petições Impostos 32.4 (1884-1889), 
No transcorrer do primeiro semestre de 1882, para aumentar seu quadro funcional, Antônio José Maia \& Cia. também recrutou trabalhadoras e trabalhadores por meio dos principais jornais pernambucanos. Em finais de janeiro, anúncios solicitavam "fulistas, propriagistas e costureiras que tenham alguma prática de forrar e debruar". ${ }^{48}$ Mais costureiras e oficiais de chapeleiro foram convocados em fevereiro. ${ }^{49}$ No mês seguinte, a fábrica a vapor de chapéus buscava "meninos de 14 anos para cima ou mesmo rapazes que queiram aprender o ofício de chapeleiro, dando-se desde logo uma gratificação regular e sendo aumentado conforme a habilidade de cada um". ${ }^{50}$ Especialmente nesse anúncio, demonstrava-se certo respeito às normas do Regulamento da Companhia de Aprendizes Artífices do Arsenal de Marinha, exceto no tocante à idade do recrutado. Nos últimos dias de abril, foram convocados outros grupos de "costureiras que tenham bastante prática da costura". ${ }^{51}$ Por fim, em toda a segunda quinzena de junho, registraram-se nos periódicos recifenses novas solicitações "de meninos e rapazes de idade de 14 a 18 anos" para a aprendizagem do "ofício de chapelaria, recebendo desde logo uma pequena retribuição". ${ }^{52}$

As contratações e os recrutamentos que antecederam a abertura oficial da fábrica a vapor de chapéus permitem que conheçamos um pouco desse ramo industrial. No século XIX, fula e apropriagem eram as partes mais importantes do processo produtivo. Os fulistas distinguiam as matérias-primas, amaciavam-nas, apertavam-nas e preparavam a primeira enformação. Em seguida, os apropriagistas faziam os acabamentos mais refinados. Esses dois operários eram os mais especializados, podendo chegar à qualificação de mestre. Fula e apropriagem eram atividades eminentemente masculinas e estavam no topo das hierarquias profissionais, podendo ser passadas de pais para filhos. O arcador era um auxiliar na feitura do chapéu. As afinadeiras e as costureiras participavam da fase de acabamentos. As primeiras retiravam os excessos de pelo dos produtos. As outras, como vimos nos jornais pernambucanos, ficavam encarregadas de fazer os forros e os ornamentos. As mulheres estavam na base das hierarquias profissionais. ${ }^{53}$ Parte dessas informações são corroboradas quando observamos os perfis dos primeiros contratados por Antônio José Maia \& Cia. Completavam os trabalhos da chapelaria: tintureiros, cartoneiros e engomadores.

A documentação disponível de Antônio José Maia \& Cia. permite atestar a veracidade de um dado muito importante para essa seção, sobre a existência de aproximadamente 80 operários e operárias no dia da abertura oficial das portas da fábrica a vapor de chapéus. As

Arquivo Público Estadual Jordão Emerenciano (doravante APEJE), Recife-PE, Fundo: petições; natureza: manuscrito.

48 Jornal do Recife, Recife, 26, 27, 29 e 31 jan. 1882. Disponível em: http://memoria.bn.br/hdb/periodico.aspx. Acesso em: 17 ago. 2019.

49 Jornal do Recife, Recife, 11 e 12 fev. 1882. Disponível em: http://memoria.bn.br/hdb/periodico.aspx. Acesso em: 17 ago. 2019.

50 Jornal do Recife, Recife, 7, 10, 11 e 12 mar. 1882. Disponível em: http://memoria.bn.br/hdb/periodico.aspx. Acesso em: 17 ago. 2019.

51 Jornal do Recife, Recife, 22, 23 e 26 abr. 1882. Disponível em: http://memoria.bn.br/hdb/periodico.aspx. Acesso em: 17 ago. 2019.

52 Jornal do Recife, Recife, 18, 20, 21, 22, 23, 27 e 29 jun. 1882. Disponível em: http://memoria.bn.br/hdb/ periodico.aspx. Acesso em: 17 ago. 2019.

53 Até aqui, tudo em: CRUZ, Stéphanie Gomes da. Os usos e a produção do chapéu em Portugal: uma experiência de mediação patrimonial no Museu da Chapelaria. Dissertação (Mestrado em História e Patrimônio) - Faculdade de Letras, Universidade do Porto, Porto, 2015. p. 75-76, 80 e 86. MÓNICA, Maria Filomena. Uma aristocracia operária: os chapeleiros (1870-1914). Análise Social, Lisboa, v. XV, n. 60, p. 942 e 944, $1979\left(4^{\circ}\right)$. RAMADA, op. cit., p. 292. 
fontes indicam que o $68^{\circ}$ funcionário admitido no negócio foi Maria dos Prazeres, uma nacional de 20 anos que aceitou o lugar de aprendiz de costureira. O registro foi feito pelos patrões no dia 27 de junho. Contudo, a partir dele, há hiatos no fichamento das datas de contratação. Depois da entrada de Maria dos Prazeres, mais 34 admissões foram feitas sem o respectivo dado. As datas voltaram a surgir a partir da $103^{a}$ admissão, ocorrida em 27 de agosto. Alexandrina da Conceição também era brasileira, tinha 27 anos e, como sua colega, iniciava sua aprendizagem no ofício de costureira. Entre os dias 28 de junho e 2 de julho, portanto, há indícios de que os proprietários tiveram tempo suficiente para contratar até 12 trabalhadores. Por razões metodológicas, para fugirmos de imprecisões quantitativas, assumiremos o total de 80 trabalhadoras e trabalhadores nas festividades do dia 3 de julho, para facilitar nossas análises sobre seus perfis etários, profissionais, de gênero e nacionais.

Com média de 28,45 anos, 11 trabalhadores nascidos em nosso país eram homens adultos $-13,75 \%$ das operárias e dos operários em atividade no dia 3 de julho de 1882 . Eles ocupavam os mais variados ofícios e possuíam diferentes níveis de aperfeiçoamento. Desses, oito eram profissionais qualificados. Existiam cinco oficiais de apropriagem, um oficial de cartoneiro, um oficial de carpina e um maquinista. ${ }^{54}$ Os dois primeiros grupos profissionais poderiam ser egressos das poucas manufaturas recifenses de chapéus ou até mesmo terem sido deslocados da Chapelaria Industrial, que era propriedade de Antônio José Maia \& Irmão. Depois da abertura da fábrica a vapor de chapéus, o prédio da Rua do Barão da Vitória, n. 36, passou a ser seu depósito. ${ }^{55} \mathrm{O}$ oficial de carpina, ramo da carpintaria ligado às edificações, certamente foi contratado para fazer reparos nos equipamentos de madeira que eram essenciais para a produção, além de estar de prontidão para fazer os consertos precisos no prédio da Rua do Visconde de Goiana, n. 147. O maquinista, que operava o "moderno" equipamento vindo da cidade do Porto, pode ter adquirido expertise profissional, por exemplo, em espaços como os arsenais de Guerra e de Marinha.

Os outros três brasileiros maiores foram empregados como aprendizes de fulista, apropriagista e foguista. ${ }^{56}$ Os dois primeiros estavam diretamente subordinados aos mestres portugueses. O outro, ao maquinista nascido em nosso país, já que o foguista era responsável pela alimentação da caldeira da máquina a vapor. Há duas questões, relacionais, que se desdobram desse quadro. A primeira delas nos remete para a proletarização das profissões artesanais. Outrora, os antigos mestres possuíam os meios de produção e escolhiam seus aprendizes entre os meninos que poderiam, lenta e progressivamente, aprender os segredos dos seus ofícios. No momento em que o capitalista tomava para si os meios de produção e controlava o mercado de trabalho, conquistava o poder de empregar os mestres e contratar adultos aprendizes a baixo custo. Com isso, impunha a breve assimilação dos processos produtivos, para que o operário fosse minimamente preparado em curto espaço de tempo. ${ }^{57}$

54 Até aqui, tudo em: Maço “Impostos, Recife, 1886, Ant ${ }^{\circ} J^{\mathrm{e}}$ Maia \& Cia”, Petições Impostos 32.4 (1884-1889), APEJE, Recife-PE, Fundo: petições; natureza: manuscrito.

55 Diário de Pernambuco, Recife, 24 jun., 17 jul. e 5 set. 1884. Disponível em: http://memoria.bn.br/hdb/ periodico.aspx. Acesso em: 18 ago. 2019. Jornal do Recife, Recife, 22 ago. 1885. Disponível em: http:// memoria.bn.br/hdb/periodico.aspx. Acesso em: 18 ago. 2019.

56 Até aqui, tudo em: Maço “Impostos, Recife, 1886, Ant ${ }^{\circ}$ Je Maia \& Cia”, Petições Impostos 32.4 (1884-1889), APEJE, Recife-PE, Fundo: petições; natureza: manuscrito.

57 Entre outros, consultar: RUGIU, Antônio Santoni. Nostalgia do mestre artesão. Campinas: Autores Associados, 1998. PEREIRA, Miriam Halpern. Artesãos, operários e o liberalismo: dos privilégios corporativos 
Dialogicamente, surge a outra questão. Na crítica economia pernambucana dos anos 1880 , a falta de empregos exigia que os adultos pobres e desqualificados se submetessem à aprendizagem de um novo ofício e à superexploração de sua força de trabalho.

As mulheres maiores nascidas em nosso país eram oito ( $10 \%$ da força de trabalho em 3 de julho) e tinham a média de 26,37 anos - bem próxima à dos homens, seus compatriotas. Todas, sem exceção, assim como a própria Maria dos Prazeres, citada anteriormente, foram empregadas como aprendizes de costureira. ${ }^{58}$ Para compreendermos essa peculiaridade, não basta estar ciente do desemprego em conjunturas recessivas, da proletarização e da falta de oportunidades para se qualificar profissionalmente, mas também da condição feminina em uma sociedade patriarcal. Ao realizar estudos sobre a honra e os usos da justiça pelas mulheres pobres pernambucanas, Maria Emília Vasconcelos dos Santos afirma que, no século XIX, elas quase sempre foram empregadas como amas de leite, cozinheiras, lavadeiras, amas-secas, lavadeiras, engomadeiras e costureiras. Segundo a historiadora, o Colégio das Órfãs era um dos poucos espaços em que se poderia alcançar algum aperfeiçoamento naquele último ofício, por possuir máquinas de costura, tecidos e aulas práticas. ${ }^{59}$ Portanto, as trabalhadoras contratadas por Antônio José Maia \& Cia., inexperientes, realizaram os serviços mais simples de forração e de ornamentação.

Vimos que, no início das operações da fábrica a vapor de chapéus, existiam 16 estrangeiros maiores, operários portugueses qualificados, trabalhando na Rua do Visconde de Goiana, n. 147. Até o dia da abertura oficial das portas do empreendimento fabril, havia chegado mais quatro lusitanos para produzir em suas dependências: três oficiais de apropriagem e um oficial de fula. Um deles foi contratado no dia 7 de março e os outros três em $1^{\circ}$ de maio de 1882. Não há indícios de que esses forasteiros tenham saído de seu país natal para cumprirem contratos na firma de Antônio José Maia \& Cia. Da mesma forma, sobre o quarteto, nada também indica que fossem antigos moradores da capital pernambucana. A média etária desse pequeno grupo era 33,75 anos. Como não sabemos as idades de seus outros 16 compatriotas, propomos, por amostragem, que todos eles, mestres e oficiais dos mais variados ofícios chapeleiros, eram homens maduros, possuíam larga experiência profissional e aprenderam seus ofícios segundo as antigas regras das tradições artesanais. Esses 20 portugueses adultos e especializados compunham $25 \%$ da força de trabalho presente no dia 3 de julho de 1882.

No dia da inauguração, junto das duas afinadeiras portuguesas que foram admitidas em 2 de janeiro, outras três compatriotas (qualificadas e com mais de 19 anos) também compuseram o quadro funcional da fábrica a vapor de chapéus. Os registros falham na ocupação de uma delas, enquanto as outras eram costureiras. Das cinco empregadas de

para o direito ao trabalho (1820-1840). Ler História, n. 14, p. 41-86, 1988. PROTHERO, lorwerth. Artisans \& politics in early nineteenth-century London: John Gast and his times. Londres: University Paperbacks, 1979. STOTT, Richard. Artisans and capitalist development. Journal of the Early Republic, v. 16, n. 2, p. 257-271, 1996.

58 Maço “Impostos, Recife, 1886, Ant ${ }^{\circ}$ Je Maia \& Cia", Petições Impostos 32.4 (1884-1889), APEJE, Recife-PE, Fundo: petições; natureza: manuscrito.

59 SANTOS, Maria Emília Vasconcelos dos. "Moças honestas" ou "meninas perdidas": um estudo sobre a honra e os usos da justiça pelas mulheres pobres em Pernambuco (1860-1888). Dissertação (Mestrado em História Social) - Centro de Filosofia e Ciências Humanas, Universidade Federal de Pernambuco, Recife, 2007. p. 28 e 35. 
Antônio José Maia \& Cia. (6,25\% da força de trabalho em 3 de julho de 1882), sabemos a idade de três, com a faixa etária de 28,33 anos. Caso assumamos que, por amostragem, todas tivessem quase 30 anos em média, tudo indica que fossem bastante experimentadas na afinação e na costura - assim como seus patrícios, que eram mestres e oficiais em suas especialidades. Contudo, além de as mulheres estarem no mais baixo escalão das hierarquias chapeleiras, não desfrutavam das mesmas prerrogativas das antigas corporações de ofício. Enquanto os homens, de acordo com as suas qualificações, eram reconhecidos como oficiais ou mestres, elas não ostentavam títulos que demonstrassem seu grau de perícia. Se boa, muita boa ou excelente profissional, eram apenas definidas por colegas e pelo público em geral como afinadeiras e costureiras.

Havia também 36 menores na fábrica a vapor de chapéus - $45 \%$ da mão de obra empregada. Um deles $(2,78 \%)$ era oficial de apropriagem. Os outros $(97,22 \%)$ eram aprendizes. Dentre esses, um jovem português, com 16 anos, dava os primeiros passos na apropriagem. Com 14, uma nacional aprendia os princípios da costura, estando em mesma condição de suas compatriotas adultas. A esmagadora maioria, representada por 33 indivíduos, era composta por meninos e por rapazes nativos entre 13 e 18. Estatisticamente, eles possuíam a média etária de 15,27 anos. ${ }^{60}$ Nas oficinas do empreendimento fabril, 17 eram orientados pelo mestre fulista e 12 pelo mestre apropriagista $-87,88 \%$ se iniciava nas principais profissões da chapelaria. Do restante, um aprendia o ofício de engomador, um de cartoneiro e dois de arcador. Ao tomarmos o Censo de 1872 como parâmetro, a maior parte deles e a própria aprendiz de costureira deveriam estar na escola, já que, no documento, esse deveria ser o destino de livres e de libertos entre 6 e 15 anos. Contudo, a pobreza, a falta de políticas públicas e a busca por sobrevivência faziam com que apenas $19,24 \%$ da respectiva população recifense bem ou mal estudasse. ${ }^{61}$

Do ponto de vista familiar, faltam dados sobre a filiação do jovem estrangeiro. A moça brasileira tinha o nome de sua mãe inscrito nas fontes. No contingente de meninos e de rapazes nativos, cinco $(15,15 \%)$ possuíam o mesmo tipo de registro. Não é possível saber se eram filhos naturais ou legítimos. Sete aprendizes nacionais $(21,21 \%)$ tinham sua filiação ignorada. ${ }^{62}$ Provavelmente fossem enjeitados e órfãos enviados pelas autoridades para aprender um ofício. Segundo Vera Lúcia Braga de Moura, essa era uma prática muito comum em Pernambuco do século XIX, para torná-los "úteis". ${ }^{63}$ Apenas um dos menores $(3,03 \%)$ não apresentava dados. A maior parte, 20 (60,61\%), tinha anotado o nome do pai. Desses, 17 (pouco mais da metade dos meninos e rapazes) possuíam os mesmos sobrenomes paternos, o que indica que fossem filhos legítimos. Podemos sugerir que as famílias socialmente reconhecidas e chefiadas por homens tiveram mais chances de encaminhar seus descendentes para o emprego. Comparativamente, observamos a mesma tendência quando o assunto é o envio de crianças pobres à escola primária pernambucana. Adriana

60 Até aqui, tudo em: Maço "Impostos, Recife, 1886, Ant ${ }^{\circ}$ Je Maia \& Cia”, Petições Impostos 32.4 (1884-1889), APEJE, Recife-PE, Fundo: petições; natureza: manuscrito.

61 MAC CORD, Marcelo, 2019, p. 5-6.

62 Até aqui, tudo em: Maço “Impostos, Recife, 1886, Ant ${ }^{\circ} J^{e}$ Maia \& Cia”, Petições Impostos 32.4 (1884-1889), APEJE, Recife-PE, Fundo: petições; natureza: manuscrito.

63 MOURA, Vera Lúcia Braga de. Pequenos aprendizes: assistência à infância desvalida em Pernambuco no século XIX. Dissertação (Mestrado em História Social) - Centro de Filosofia e Ciências Humanas, Universidade Federal de Pernambuco, Recife, 2003. p. 68-69. 
Maria Paulo da Silva fez essa constatação ao estudar a primeira metade do oitocentos. ${ }^{64}$

Deve ser muito bem calibrada a percepção de que o referido grupo social encontrava vantagens no acesso de seus filhos ao emprego e à instrução, para que ambos não sejam entendidos como atividades complementares. Para crianças e jovens pobres, trabalho e estudo eram ocupações extremamente conflitantes. A historiografia da educação demonstra que a maior parte deles, matriculados em escolas públicas matutinas, não conseguiam dar continuidade aos seus estudos formais. Apesar de muitos deles iniciarem o aprendizado da leitura e da escrita, grande parte precisava abandonar as salas de aula, porque necessitava sobreviver por meio do suor do próprio rosto e contribuir com a renda familiar. Até mesmo com o advento das aulas noturnas, na segunda metade do século XIX, muitos meninos e rapazes não podiam seguir ao encontro de seus professores, pois estavam cansados e mal alimentados. ${ }^{65}$ Por mais que as famílias pernambucanas chefiadas por homens e socialmente reconhecidas experimentassem menos impedimentos para instruir seus descendentes, a maior parte delas engordava as estatísticas da evasão escolar por causa de questões socioeconômicas.

Do grupo de menores aprendizes nascidos no país (33 homens e uma mulher), 15 foram registrados como internos, ou seja, com o direito de usufruir as mercês oferecidas pela Lei $n^{\circ}$ 1.289. Recordemos que Antônio José Maia \& Cia. deveria sustentar, vestir, medicar e remunerar o total de 12 meninos e jovens pernambucanos. Além de contratá-los em número superior às exigências legais, os capitalistas portugueses inauguraram seu negócio protegendo $44,11 \%$ dos menores nativos que trabalhavam na Rua do Visconde de Goiana. Contudo, a prioridade foi dada para os aprendizes de fula e de apropriagem, que ocuparam 14 vagas internas. Um principiante do ofício de engomador completou a lista. Todos eram jovens com a média etária de 15 anos e tinham o nome da mãe ou do pai registrados nos livros da empresa. Esse último parente surgiu 12 vezes, sendo que nove meninos e rapazes tinham o mesmo sobrenome paterno, algo que indica com mais segurança serem filhos legítimos. ${ }^{66}$ Como podemos concluir, nenhum dos agraciados era órfão ou enjeitado, para quem a benesse parecia ser mais justa. Assim, reforçamos a sugestão de que, mesmo pobres, as famílias socialmente reconhecidas e chefiadas por homens tinham mais oportunidades.

64 SILVA, Adriana Maria Paulo da. Processos de construção das práticas de escolarização em Pernambuco, em fins do século XVIII e a primeira metade do século XIX. Recife: Editora Universitária UFPE, 2007. p. 298-341.

65 Entre outros, consultar VEIGA, Cynthia Greive. Escola pública para os negros e os pobres no Brasil: uma invenção imperial. Revista Brasileira de História da Educação, Rio de Janeiro, v. 13, n. 39, p. 502-516, 2008. BARROS, Surya Aaronovich Pombo de. Negrinhos que por ahi andão: a escolarização da população negra em São Paulo (1870-1920). Dissertação (Mestrado em Educação) - Faculdade de Educação, Universidade de São Paulo, 2005. p. 80-81 e 130. SANTOS, Yan Soares. A Sociedade Propagadora da Instrução pública e suas ações de qualificação profissional em Recife (1872-1903). Dissertação (Mestrado em Educação) - Faculdade de Educação, Universidade Federal de Pernambuco, 2014. p. 71 e 91. COSTA, Ana Luiza Jesus da. $\mathbf{O}$ educar-se das classes populares oitocentistas no Rio de Janeiro entre a escolarização e a experiência. Tese (Doutorado em Educação) - Faculdade de Educação, Universidade de São Paulo, 2012.

66 Até aqui, tudo em: Maço "Impostos, Recife, 1886, Ant ${ }^{\circ} J^{\mathrm{J}}$ Maia \& Cia”, Petições Impostos 32.4 (1884-1889), APEJE, Recife-PE, Fundo: petições; natureza: manuscrito. 


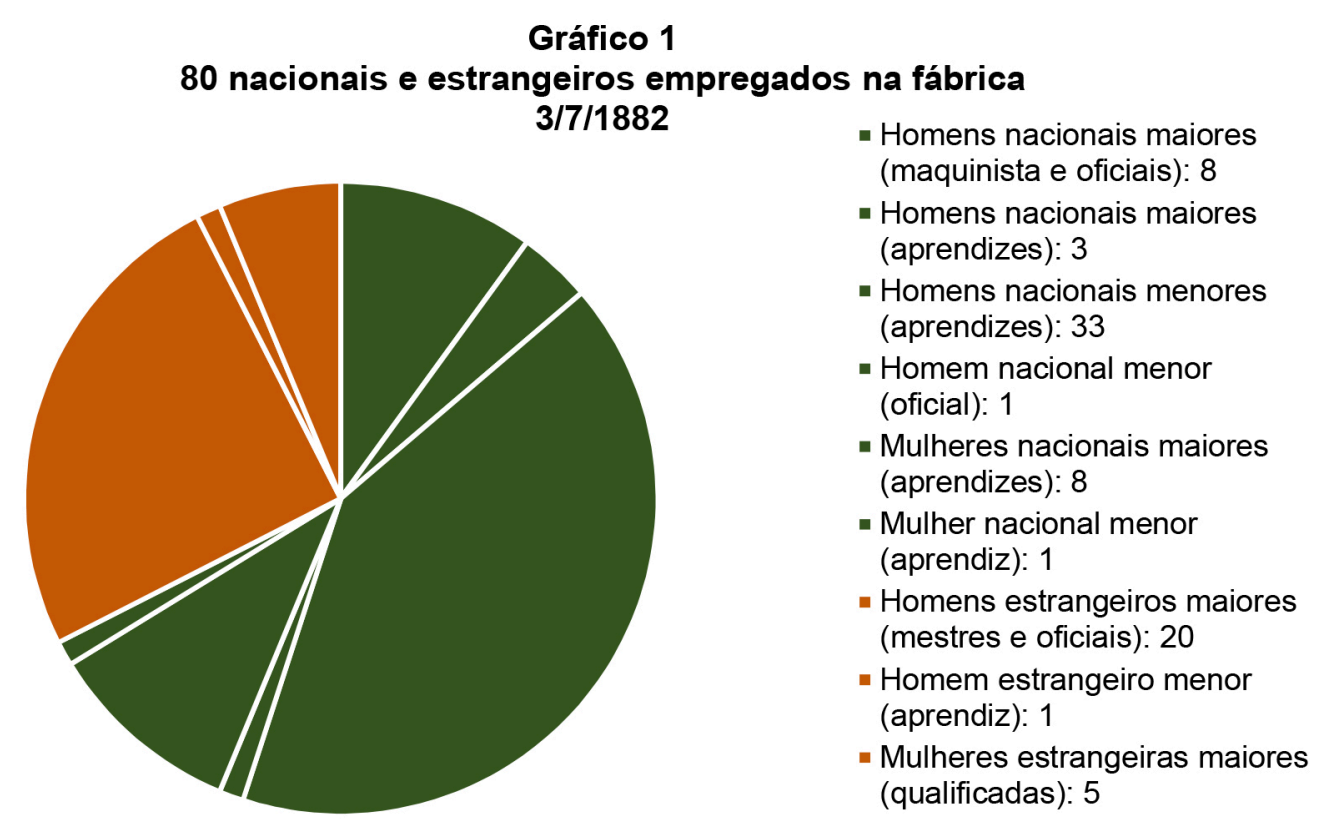

Fonte: Maço “Impostos, Recife, 1886, Ant ${ }^{\circ}$ Je Maia \& Cia.", Petições Impostos 32.4 (1884-1889), Arquivo Público Estadual Jordão Emerenciano (Recife-PE), Fundo: petições; natureza: manuscrito.

O gráfico 1 demonstra e ratifica que a força de trabalho da fábrica a vapor de chapéus era eminentemente masculina quando da abertura de suas portas. Eram 66 homens $(82,5 \%$ de todo o pessoal empregado) e 14 mulheres (17,5\%) envolvidos no processo produtivo. No topo da pirâmide profissional, havia dois portugueses (2,5\% dos contratados): um mestre fulista e um mestre apropriagista. Logo abaixo, oito brasileiros (10\%) e 18 lusitanos (22,5\%) ocupavam o lugar de oficial de apropriagem, fula, arcador e cartoneiro. No terceiro nível, cinco estrangeiras (6,25\%) dominavam os processos de afinação e de costura. Na base da pirâmide fabril, 33 menores $(41,25 \%)$ e três maiores $(3,75 \%)$ nativos somavam forças com um jovem forasteiro $(1,25 \%)$ na aprendizagem dos ofícios de fula, apropriagem, arcador, cartoneiro e engomador. Logo abaixo de seus colegas neófitos, uma menor $(1,25 \%)$ e oito maiores $(10 \%)$ nascidas no país davam seus primeiros passos na costura. Dentre todos os menores listados, 15 meninos e rapazes aprendizes de fula, apropriagem e engomador desfrutavam da proteção da Lei no 1.289. O maquinista brasileiro (1,25\%), trabalhador qualificado, possuía status diferenciado no negócio, com nível semelhante ao dos mestres.

Se os empregadores contrataram 15 menores aprendizes nacionais sob os auspícios da Lei $n^{\circ} 1.289$, superando um pouco a exigência legal, é preciso fazer uma observação. Para baratear a produção, eles recrutaram mais 18 nativos, uma nativa e um estrangeiro com o mesmo perfil etário-profissional. Do total de 34 meninos, rapazes e moça brasileiros empregados pela fábrica a vapor de chapéus, 19 (55,88\%) contavam somente com seus parcos jornais. O que Antônio José Maia \& Cia. dava com uma de suas mãos ao respeitar a legislação, tirava com a outra ao atuar como capitalista. Pensando em minimizar ainda mais os custos, a empresa também empregou 11 adultos brasileiros sem experiência no ramo da chapelaria, para que cumprissem tarefas primárias com mísera remuneração. Talvez aquelas que os corpos mais frágeis dos menores não aguentassem executar. Muitos pernambucanos poderiam alegar, com alguma razão, que a função de aprendiz oferecia oportunidades de 
profissionalização para meninos, jovens e adultos inexperientes. Contudo, esse grupo compunha $57,5 \%$ da força de trabalho do negócio, o que nos permite reforçar a perspectiva de que tamanho contingente tinha mais intenções econômicas que altruístas.

O Diário de Pernambuco de 4 de julho de 1882, portanto, exagerava quando afirmou que quase todos os operários e as operárias da fábrica a vapor de chapéus eram nacionais. O gráfico 1 indica que 54 brasileiros $(67,5 \%)$ compunham a força de trabalho de Antônio José Maia \& Cia. no dia da inauguração do empreendimento. Os imigrantes, $26-32,5 \%$. Podemos afirmar que 2/3 dos empregados do negócio era nativa, ou seja, ampla maioria. A tabulação também deixa evidente outro aspecto omitido pelo articulista. Dos 80 postos de trabalho abertos, 34 (42,5\%) eram especializados, enquanto 46 (57,5\%) não exigiam qualificação. Dentre os primeiros, os portugueses abocanharam 25 vagas $(73,53 \%)$, sobrando apenas $9(26,47 \%)$ para os brasileiros. Nos outros postos menos prestigiados, ligados aos primeiros passos do tirocínio fabril, os forasteiros se colocaram em apenas um $(2,17 \%)$, mas os nativos estiveram, agora sim, em quase todos: $45-97,83 \%$. Por mais que a Rua do Visconde de Goiana contasse, em grande parte, com mão de obra nascida em nosso país (fato que respondia às demandas históricas dos pernambucanos por empregos na capital), percebemos que suas ocupações, de forma geral, eram de baixa qualidade.

\section{A grande rotatividade da mão de obra na fábrica a vapor de chapéus.}

DESDE O PRIMEIRO DIA de contratações, 2 de janeiro de 1882, até a data em que Antônio José Maia \& Cia. produziu seu relatório para o fisco pernambucano, 6 de novembro de 1886, a fábrica a vapor de chapéus registrava quase cinco anos de operação. Nesse espaço de tempo, em números absolutos, os donos do empreendimento contrataram 450 operários e operárias. Concorrentemente, 345 foram demitidos e/ou deixaram o emprego. Em outras palavras, os três patrões portugueses admitiram, em média, um trabalhador a cada 3,92 dias. Por sua vez, demissões ou pedidos de dispensa ocorreram a cada 5,11. Parece evidente que existiu grande rotatividade de mão de obra na Rua do Visconde de Goiana, n. 147. Do ponto de vista das elites letradas e proprietárias, isso seria fruto da indolência e da preguiça do "operário nômade, que hoje trabalha aqui e amanhã acolá", pois sempre era propenso à vadiagem. ${ }^{67}$ Essa sentença foi proferida por Francisco Belisário em seu livro O sistema eleitoral, publicado em 1872. Contudo, sintetizava a percepção da maior parte dos homens públicos e dos capitalistas brasileiros. Fugindo de simplificações classistas desse tipo, podemos propor uma série de outros motivos para os números observados.

Em 1953, João da Silva Correia, importante escritor e jornalista português, publicou a primeira edição do seu romance Unhas negras. A trama foi baseada em suas memórias de infância em São João da Madeira, onde testemunhou, nos primeiros anos do século XX, o duro cotidiano dos operários das fábricas de chapéus, assim como suas formas de organização e suas lutas por direitos. Segundo o autor, dentre todos os trabalhadores que formavam a

67 SOUZA, Francisco Belisário Soares de. O sistema eleitoral no Império. Brasília: Senado Federal, 1979. p. 31-32. 
categoria, os fulistas eram "figuras de fadiga mais apagadas, pálidas do vapor tóxico das fulas". Esses profissionais, continua a narrativa, sempre trabalhavam "seminus, com avental grosseiro à cinta para resguardo das partes contra a ação corrosiva dos sulfetos". Se as genitálias ficavam mais ou menos protegidas, as mãos ficavam completamente estragadas. Elas ostentavam "unhas negras deformadas e grossas, muito roída dos ácidos, a rematar os dedos escaldados". Por causa disso, conclui, "há quem ainda chame as fulas, mesmo as modernas fulas, inferno dos vivos". ${ }^{68} \mathrm{~A}$ historiografia ratifica a verossimilhança do relato feito pelo lusitano, tendo em vista as péssimas condições de trabalho nas fábricas de chapéus francesas (no século XVIII) e estadunidenses (no XIX). ${ }^{69}$

De uma forma geral, não somente o fulista sofria com o ambiente extremamente insalubre das fábricas a vapor de chapéus. Por causa dos elementos químicos corrosivos e voláteis que eram utilizados no processo de produção, a atmosfera que envolvia os operários era bastante pesada e muitas vezes irrespirável. Junte-se a isso a fuligem e a fumaça que pairavam no ar, oriundas da queima dos combustíveis que alimentavam as caldeiras. Essas, por si só, ainda aumentavam sensivelmente a temperatura em seu entorno. ${ }^{70} \mathrm{Na}$ documentação produzida por Antônio José Maia \& Cia., é possível observar que o menor Antônio Luiz França, nacional com 16 anos, interno protegido pela Lei $n \circ 1.289$, que foi contratado logo no início das operações, morreu enquanto estava em tratamento no Hospital Português de Beneficência. ${ }^{71} \mathrm{Na}$ medida em que os três proprietários do negócio fabril eram lusitanos com posses, parece evidente sua influência para conseguir algum leito na casa de saúde fundada por seus patrícios. ${ }^{72}$ Não podemos afirmar qual o motivo do óbito do jovem aprendiz, mas basta saber que o mesmo dava seus primeiros passos na fula, oficina que impunha péssimas condições de trabalho.

Não bastassem os problemas ligados à integridade física dos operários e das operárias, outro somava-se a eles. Tendo em vista os limites das fontes, nada sabemos sobre o valor (e a regularidade no pagamento) das diárias recebidas pelo conjunto dos trabalhadores da fábrica a vapor de chapéus. Entretanto, os aprendizes recebiam jornais de $\$ 500 \mathrm{Rs}^{73}$ Como sabemos, essa quantia era superior àquela que havia sido determinada pelo Decreto $\mathrm{n}^{\circ} 2.615$, de 21 de julho de 1860, que reorientou os arsenais de Marinha da Corte, da Bahia e de Pernambuco. Para os menores internos, protegidos pela Lei $n^{\circ} 1.289$, pode ser que essa pequena remuneração fosse compensada pelos medicamentos, comedorias, alojamento e roupas fornecidos pelos empregadores. Contudo, para os neófitos dos mais variados gêneros e idades, que voltavam para suas casas ao final de uma dura jornada de trabalho, o montante era irrisório para satisfazer suas necessidades básicas. Em meados do século XIX, por exemplo, um mestre-pedreiro pernambucano, homem pardo bem-sucedido, chegava a gastar

68 Até aqui, tudo em: CORREIA, João da Silva. Unhas negras. Lisboa: Livraria Editora Guimarães \& Cia, 1953. p. 38, 149 e 151-152.

69 SONENSCHER, Michel. The hatters of Eighteenth-Century France. Berkeley and Los Angeles: University of California Press, 1987. BENSMAN, David. The pratice of solidarity: American hat finishers in the Ninenteenth-Century. Urbana: University of Illinois, 1985.

70 SANTOS, op. cit., p. 813-814. MÓNICA, op. cit., p. 942 et seq. CORREIA, op. cit., passim.

71 Maço "Impostos, Recife, 1886, Ant ${ }^{\circ}$ Je Maia \& Cia", Petições Impostos 32.4 (1884-1889), APEJE, Recife-PE, Fundo: petições; natureza: manuscrito.

72 Para saber mais sobre o Hospital Português de Beneficência, fundado, em 1855, consultar: CÂMARA, 2013, passim.

73 Maço "Impostos, Recife, 1886, Ant ${ }^{\circ}$ Je Maia \& Cia", Petições Impostos 32.4 (1884-1889), APEJE, Recife-PE, Fundo: petições; natureza: manuscrito. 
mensalmente, em média, $12 \$ 000$ Rs somente com pães. ${ }^{74}$ Se um empregado da chapelaria conseguisse serviços como aprendiz por 30 dias corridos, receberia $15 \$ 000$ Rs.

A disciplina imposta pelos chefes da fábrica a vapor de chapéus também deve ter gerado muita insatisfação nos operários. Comparativamente, no Diário de Pernambuco de 6 de fevereiro de 1887, José Alfredo de Almeida Soares comunicava "ao comércio" que, desde o dia 3, havia se demitido da empresa Antônio José Maia \& Cia. por não mais tolerar "as faltas de delicadeza e os maus-tratos que o gerente daquela casa, o sr. Baltazar, dá às pessoas que têm a infelicidade de ali serem empregadas". ${ }^{75} \mathrm{O}$ pedido de demissão também foi publicado pelos donos do negócio naquela mesma edição, mas apenas como um informe. É bastante provável que o ex-funcionário fosse um dos caixeiros responsáveis pela venda dos chapéus. Encontramos um homônimo que havia sido, em janeiro de 1886, caixeiro de Adolpho \& Ferrão. ${ }^{76}$ Independentemente da nacionalidade e da real função de José Alfredo, em tempos de desagregação do escravismo, muitos homens livres, e libertos, não aceitavam formas senhoriais de tratamento que os nivelassem aos cativos. ${ }^{77}$ Talvez fosse melhor labutar aqui hoje e acolá amanhã, e exercitar possibilidades de escolha, do que se submeter cotidianamente aos mesmos "baltazares".

Demonstradas, de forma geral, algumas das possíveis motivações para a grande rotatividade da mão de obra empregada na fábrica a vapor de chapéus, conheceremos o perfil das 345 pessoas que foram demitidas ou deixaram seus empregos até o dia 6 de novembro de 1886. Essa foi a data da feitura do relatório de Antônio José Maia \& Cia., enviado às autoridades públicas. Daquele montante, pouco mais da metade, 182 (52,8\% da antiga força de trabalho), era composta por brasileiros e por estrangeiros com menos de 19 anos. Desses, $167(91,76 \%)$ eram meninos e rapazes nativos. Com a média etária de 14,75 anos, 85 iniciaram sua aprendizagem no ofício de apropriagem e 57 no de fulista, ou seja, as principais atividades da chapelaria ocuparam 142 indivíduos que passaram pela Rua do Visconde de Goiana. Outros 24 se dividiram entre as atividades de arcador, cartoneiro, engomador, tintureiro e afinador. O jovem João Leio, de 18 anos, considerado menor na documentação, com pais ignorados, talvez órfão ou enjeitado, serviu como criado. A falta de sobrenome e a ocupação podem indicar que fosse escravizado. Houve também significativa diminuição dos menores assistidos pela Lei $n^{\circ} 1.289$, pois 11 se tornaram maiores ou deixaram as oficinas.

Do ponto de vista familiar, encontramos importantes dados sobre os 167 meninos e rapazes nacionais que não mais faziam parte do negócio de Antônio José Maia \& Cia., quando da feitura de seu relatório às autoridades fiscais pernambucanas. Daquele número, $57(34,13 \%)$ tinham o nome de suas mães registrados na documentação. Por causa dos limites apresentados pelas fontes, não podemos afirmar se eram filhos legítimos ou naturais. Por sua vez, com a filiação declarada como desconhecida, havia $43(25,75 \%)$ ex-aprendizes

74 MAC CORD, Marcelo. Francisco José Gomes de Santa Rosa: experiências de um mestre pedreiro pardo e pernambucano no oitocentos. Afro-Ásia, Salvador, n. 49, p. 220, 2014.

75 Diário de Pernambuco, Recife, 6 fev. 1887. Disponível em: http://memoria.bn.br/hdb/periodico.aspx. Acesso em: 20 ago. 2019.

76 Diário de Pernambuco, Recife, 26 jan. 1886. Disponível em: http://memoria.bn.br/hdb/periodico.aspx. Acesso em: 20 ago. 2019.

77 MAC CORD, Marcelo. Conexões atlânticas nos canteiros de obras públicas recifenses: lutas subalternas contra a precarização do trabalho. Década de 1850. Revista de História Comparada, Rio de Janeiro, v. 7 , n. 1, p. 165-166, 2013. 
das mais variadas profissões chapeleiras. Em outro momento, sugerimos que essas gentes provavelmente fossem órfãs ou enjeitadas, sendo enviadas à fábrica a vapor de chapéus pelos poderes públicos provinciais. Assim, devidamente ocupadas, elas aprenderiam algum ofício, escapariam da "vadiagem" e se tornariam "úteis" à sociedade. Em seguida, com o nome do pai anotado nos papéis, computamos 64, equivalendo a 38,32\%. Desses, 52 (pouco menos de 1/3 dos 167 menores brasileiros) tinham sobrenomes iguais aos de seus pais, o que indica sua legitimidade jurídico-familiar. Finalmente, sem qualquer dado sobre sua filiação, três $(1,8 \%)$ menores de 19 anos nascidos em nosso país completavam a lista. ${ }^{78}$

Comparativamente ao dia da inauguração da fábrica a vapor de chapéus, percebemos algo importante. Em sua abertura oficial, em 3 de julho de 1882, havia 33 meninos e rapazes nativos empregados como aprendizes. Desses, $60,61 \%$ tinham os nomes de seus pais nas fichas de admissão. Com o nome das mães, $15,15 \%$. Os prováveis órfãos e enjeitados eram $21,21 \%$, enquanto $3,03 \%$ surgiram sem dados sobre sua filiação. Contudo, no transcorrer de pouco mais de quatro anos, desde o dia festivo, sabemos que 167 menores brasileiros deixaram seus empregos voluntária ou involuntariamente. No referido espaço de tempo, encontramos uma peculiaridade em relação às admissões feitas no início da década. Entre os que foram dispensados ou pediram dispensa, $38,32 \%$ foram registrados com o nome do pai, $34,13 \%$ com o da mãe e $25,74 \%$ com o termo "ignora-se", que nos remete à orfandade ou ao abandono. Como podemos inferir, se, no início das operações, as famílias chefiadas por homens alcançaram larga vantagem na obtenção de postos de trabalho para seus filhos, na diacronia, e em termos proporcionais, esse grupo, confrontado com os outros dois, experimentou certo equilíbrio no fluxo de entradas e de saídas da Rua do Visconde de Goiana.

Para completar o total de 182 ex-menores aprendizes que passaram pela fábrica a vapor de chapéus, além dos 167 arrolados, existiu um grupo formado por 13 (7,14\%) meninas e moças nativas. Com 17 anos em média, todas trabalharam como aprendizes de costureira. A maior parte delas, nove, tinha os nomes de suas mães registradas na documentação, três o do pai e uma ignorava sua filiação. Nem sempre é possível identificar o esforço desses responsáveis para empregar dois ou mais filhos na firma de Antônio José Maia \& Cia. Contudo, na oficina de costura, em finais de 1885 , encontramos irmãs dando os primeiros passos na profissão. Anna Maria e Lourença Maria da Conceição, com respectivamente 16 e 18 anos, eram filhas de Pedro Ribeiro. Maria Francisca e Cecília Maria de Mendonça, 17 e 19, tinham Isabel Mendonça como sua mãe. Para finalizar a listagem dos ex-aprendizes, apresentaremos os dois últimos. Um deles $(0,55 \%)$ era português, tinha 16 anos, não possuía dados sobre seus ascendentes e esteve na apropriagem. O outro (0,55\%), com 14 e mesmo sobrenome de seu pai, passou pela fula. Não é possível saber sua nacionalidade, pois, na documentação, um erro o definia (simultaneamente) como nativo e forasteiro.

As mulheres brasileiras com mais de 19 anos formaram o segundo grupo com mais baixas até 6 de novembro de 1886. Elas foram 119 (34,5\% dos ex-empregados), com média etária de 23,81 anos. Todas ocuparam o lugar de aprendiz, sendo que a maioria, 112, trabalhou

78 Até aqui, tudo em: Maço "Impostos, Recife, 1886, Ant ${ }^{\circ}$ Je Maia \& Cia”, Petições Impostos 32.4 (1884-1889), APEJE, Recife-PE, Fundo: petições; natureza: manuscrito. 
na oficina de costura e sete na de afinação. ${ }^{79} \mathrm{Na}$ comparação desses dados com os do dia da inauguração da fábrica a vapor de chapéus, observamos que, no tempo, consolidou-se, de forma exponencial, a tendência de se contratar mulheres pernambucanas adultas como aprendizes - especialmente nos afazeres da costura. Ao somarmos o quantitativo dessas trabalhadoras com o de menores aprendizes, temos o superlativo total de 301 ex-operários. Um grupo social muito específico concentrou $87,3 \%$ da força de trabalho que foi dispensada ou que decidiu sair da firma de Antônio José Maia \& Cia. A mais clássica historiografia social do trabalho aponta, em termos globais, para a superexploração do trabalho de crianças, jovens e mulheres em unidades industriais da segunda metade do século XIX. Mão de obra barata e desproteção legislativa foram dois dos principais fatores que favoreceram os abusos patronais sobre essa parcela da população pobre. ${ }^{80}$

O restante dos ex-operários da fábrica a vapor de chapéus contabilizava 15 (4,3\%) brasileiros maiores. Com média de 27,6 anos, não mais estavam nas oficinas, em finais de 1886, quatro oficiais de apropriagem e um de cartoneiro. Junto deles, pelas ruas, computamos mais três oficiais de carpina. Os outros sete, quase a metade, haviam sido aprendizes, reforçando o alto nível de precarização da força de trabalho que fora um dia contratada por Antônio José \& Cia. As fontes indicam que, nesse último grupo, existiram dois pernambucanos na oficina de apropriagem, dois na de fula e um na de cartonagem. O sexto deu os passos iniciais na profissão de foguista, auxiliando o maquinista. O último frequentou os espaços da costura, que, como indicamos, era eminentemente feminino. ${ }^{81}$ Pode ser que tenha havido um equívoco no registro. No Recife dos anos 1880 , encontramos negociantes recrutando "costureiros de livros", ligados à encadernação. ${ }^{82}$ Comparativamente ao que analisamos em outro momento, sobre o emprego de adultos na função de aprendiz, seguiu-se, na rua do Visconde de Goiana, a tendência de se ferir as velhas tradições corporativas, onde estavam reservadas às crianças e aos jovens as primeiras lições do tirocínio artesanal.

Outros 22 ex-funcionários ( $6,4 \%$ da força de trabalho dispensada ou que se demitiu) foram classificados nas fontes como estrangeiros com mais de 19 anos - todos com nomes portugueses. A maior parte desses imigrantes, 21, tinha a qualificação de oficial: 15 fulistas, quatro apropriagistas, um arcador e um cartoneiro. Sabemos a idade de sete deles, o que, por amostragem, nos permite afirmar uma média etária de 32 anos e muita experiência profissional. O último da listagem era cozinheiro, responsável pela feitura das comedorias que eram servidas aos menores aprendizes protegidos pela Lei $n^{\circ} 1.289$. Por fim, as portuguesas adultas contabilizavam sete $-2 \%$ dos antigos contratados que não mais frequentavam a Rua do Visconde de Goiana, n. 147. Na quase totalidade, elas apresentavam suas idades nos papéis da fábrica a vapor de chapéus, resultando a faixa etária de 25,4 anos. Cinco forasteiras

79 Até aqui, tudo em: Maço "Impostos, Recife, 1886, Ant ${ }^{\circ}$ Je Maia \& Cia”, Petições Impostos 32.4 (1884-1889), APEJE, Recife-PE, Fundo: petições; natureza: manuscrito.

80 Entre outros, consultar: PERROT, Michelle. Os excluídos da história: operários, mulheres, prisioneiros. Rio de Janeiro: Paz e Terra, 1988. HOBSBAWM, Eric J. A era do capital: 1848-1875: Rio de Janeiro: Paz e Terra, 2009. THOMPSON, Edward Palmer. A formação da classe operária inglesa: a maldição de Adão. Rio de Janeiro: Paz e Terra, 1987.

81 Maço "Impostos, Recife, 1886, Ant ${ }^{\circ} \mathrm{Je}^{\mathrm{m}}$ Maia \& Cia", Petições Impostos 32.4 (1884-1889), APEJE, Recife-PE, Fundo: petições; natureza: manuscrito.

82 Diário de Pernambuco, Recife, 17-30 jan. 1885. Disponível em: http://memoria.bn.br/hdb/periodico.aspx. Acesso em: 22 ago. 2019. 
possuíam mão de obra qualificada para as tarefas da chapelaria, assim como seus patrícios que eram oficiais. Duas labutaram como costureiras e três como afinadeiras. Completam o arrolamento uma ex-trabalhadora que dava seus primeiros passos na profissão de costureira e outra sem dados disponíveis sobre seu ofício. ${ }^{83}$

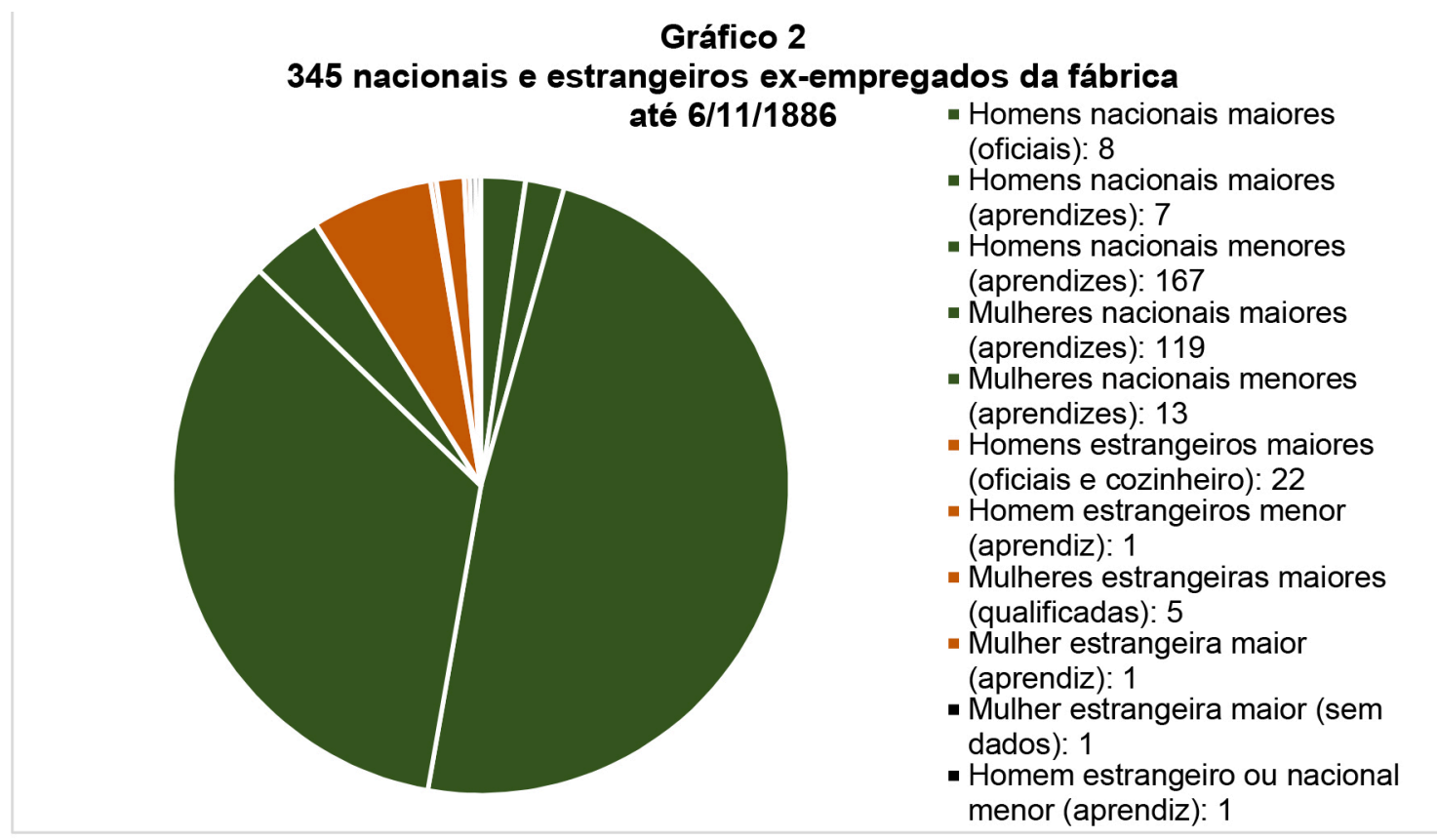

Fonte: Maço “Impostos, Recife, 1886, Ant ${ }^{\circ} \mathrm{J}^{\mathrm{e}}$ Maia \& Cia”, Petições Impostos 32.4 (1884-1889), Arquivo Público Estadual Jordão Emerenciano (Recife-PE), Fundo: petições; natureza: manuscrito.

Ao compararmos os dados dos gráficos 1 e 2, observamos que o volume de brasileiros contratados por Antônio José Maia \& Cia., desde o início das operações da fábrica a vapor de chapéus, em 2 de janeiro de 1882, cresceu exponencialmente em relação ao emprego de estrangeiros. Entretanto, o cruzamento das duas tabulações também permite afirmar que se consolidou a tendência de os trabalhadores nacionais serem admitidos em serviços de mais baixo nível técnico. Dentre os 345 operários e operárias dispensados ou que pediram demissão até 6 de novembro de 1886, impressiona o fato de que $306(88,7 \%)$ fossem nativos iniciantes em algum ofício, independentemente de seu gênero ou de sua idade. A ampla maioria desses ex-empregados da chapelaria era formada por $286(82,9 \%)$ meninos, rapazes e mulheres adultas. Devemos relembrar que, junto disso, 11 menores internos nascidos em nosso país, que foram protegidos pela Lei $n^{\circ} 1.289$, não mais permaneciam ou se tornaram adultos na Rua do Visconde de Goiana. Por causa da significativa queda desse contingente, fez-se desnecessária a presença do cozinheiro e do criado, responsáveis pelos mais diversos cuidados prescritos por aquela norma provincial.

A grande rotatividade de pessoal sem qualificação em pouco mais de quatro anos e o indicativo de desrespeito à Lei no 1.289 deixam evidentes que Antônio José Maia \& Cia. buscou diminuir seus custos de produção. Nos anos 1880, a falta de legislação protetiva para os trabalhadores pernambucanos fez com que estivessem à mercê do mercado e "dos bons ou

83 Até aqui, tudo em: Maço "Impostos, Recife, 1886, Ant ${ }^{\circ}$ Je Maia \& Cia", Petições Impostos 32.4 (1884-1889), APEJE, Recife-PE, Fundo: petições; natureza: manuscrito. 
maus corações dos industriais e seus prepostos". ${ }^{84}$ Certamente, os patrões portugueses, donos da fábrica a vapor de chapéus, fizeram contratações ao sabor das demandas. Isso manteria a necessária mão de obra na linha de montagem, de acordo com o fluxo de encomendas no grosso e das vendas no retalho. Terminado o trabalho e despachados os produtos, o excesso de contingente era dispensado sem concluir seus processos de aprendizado profissional. A mão de obra local era tão barata e abundante, que, nas fontes, não identificamos a recontratação de qualquer ex-operário demitido ou que se demitiu. Concomitantemente, por causa das duras e insalubres condições de trabalho, podemos imaginar que muitos deles nunca mais desejassem retornar às atividades das oficinas de fula, apropriagem, cartonagem, tinturaria, costura, afinação etc.

No cotejo dos gráficos 1 e 2, percebe-se ainda que, no dia 3 de julho de 1882, Antônio José Maia \& Cia. contava com 18 oficiais portugueses, oito oficiais brasileiros e cinco portuguesas qualificadas. Entre os primeiros, 14 fulistas, um arcador e três apropriagistas. No grupo com nacionais, um carpina, seis apropriagistas e um cartoneiro. Aquelas últimas estavam representadas por duas costureiras, duas afinadeiras e uma sem registro da profissão. Por sua vez, até 6 de novembro de 1886, deixaram a linha de produção o total de 21 oficiais portugueses, oito oficiais brasileiros e cinco portuguesas qualificadas. Os estrangeiros se dividiam em 15 fulistas, um arcador, quatro apropriagistas e um cartoneiro. Três carpinas, quatro apropriagistas e um cartoneiro eram ex-trabalhadores locais. Por sua vez, elas contabilizavam duas costureiras e três afinadeiras. Na relação entre os dias da inauguração e da feitura do documento entregue às autoridades, há um equilíbrio nas entradas e nas saídas dos trabalhadores especializados, fossem eles imigrantes ou pernambucanos. Desvendaremos a seguir os significados que estão por trás desses e de alguns outros números que foram apresentados nessa seção.

\section{Os operários e as operárias da fábrica a vapor de chapéus em 6 de novembro de 1886.}

No DIA EM QUE Antônio José Maia \& Cia. elaborou o relatório dirigido às autoridades fiscais pernambucanas, 6 de novembro de 1886, existiam 105 operários e operárias na linha de montagem de sua fábrica a vapor de chapéus. Comparando-se com o dia da inauguração, computamos o aumento de $31,25 \%$ do pessoal empregado pelo estabelecimento fabril. Obviamente, não podemos tomar esses números de forma absoluta, pois, como vimos, foi imensa a rotatividade da mão de obra que trabalhou na Rua do Visconde de Goiana, n. 147. Possivelmente, alguma variação entre 80 e 105 funcionários mantivesse a produção dentro do que era esperado pelos patrões e seus prepostos. Fora dessa média estimada, o quantitativo de trabalhadores empregados dependeria de uma série de fatores, como, por exemplo, a variação dos pedidos feitos por seus revendedores, fossem recifenses, pernambucanos ou regionais. Em anúncio publicado em 1885, os três sócios portugueses, donos do negócio, ofereciam seus produtos para comerciantes locais e das províncias vizinhas. ${ }^{85}$ Talvez, José

84 MORAES, Evaristo. Apontamentos de direito operário. São Paulo: LTr, 1998. p. 36.

85 Jornal do Recife, Recife, 22 ago. 1885. Disponível em: http://memoria.bn.br/hdb/periodico.aspx. Acesso em: 10 set. 2019. 
Alfredo de Almeida Soares, provável caixeiro em 1886, tenha feito curtas viagens para comercializar chapéus em locais como Paraíba e Alagoas.

No conjunto dos 105 operários e operárias, observamos que, no tempo, o total de portugueses declinou. Havia somente três adultos qualificados na fábrica a vapor de chapéus $-2,86 \%$ da força de trabalho. O mestre fulista e o mestre apropriagista eram os mesmos desde o dia 2 de janeiro de 1882, quando foram feitas as primeiras contratações de Antônio José Maia \& Cia. A permanência de ambos no empreendimento fabril garantiu a manutenção de sua coluna dorsal. Em outras palavras, eles eram o rei e a rainha no tabuleiro da linha de produção, sendo muito mais importantes para a continuidade do jogo do que outras peças secundárias e terciárias. Um oficial de fula havia sido contratado em meados de 1884, certamente para substituir algum dos seus compatriotas demitidos ou que se demitiram. Havia ainda uma menor $(0,9 \%$ dos funcionários) que fora contratada como costureira aos 6 de outubro daquele último ano, quando tinha 16. Em 6 de novembro de 1886, passado um biênio, Brizida Souza Machado completou 18 e estava ainda mais hábil em seu ofício. Um indício pode nos ajudar a compreender sua precocidade profissional e admissão. Nas fontes, o nome de seu pai é Manoel José Machado, o mesmo do mestre fulista.

No arrolamento, encontramos também 36 brasileiros com mais de 19 anos - 34,3\% dos operários e das operárias de Antônio José Maia \& Cia. A maioria absoluta, 35, tinha mão de obra aperfeiçoada (com diversos níveis de habilidade) e foi contratada entre 1882 e 1884. Para melhor conhecer esses operários, dividimo-los em quatro grupos. No primeiro deles, temos oito $(22,86 \%)$ pernambucanos que, ao chegarem à fábrica a vapor de chapéus, já eram homens maduros (em 6 de novembro de 1886, sua média etária era 35,62 anos) e muito experientes em seus ofícios. Na parte mais "moderna" do empreendimento fabril, o motor e a caldeira eram controlados por dois maquinistas e um foguista. No apoio à produção, um oficial de carpina estava de prontidão para reparar os equipamentos de madeira e fazer outros consertos que fossem necessários no prédio da Rua do Visconde de Goiana, n. 147. $\mathrm{Na}$ oficina de apropriagem encontravam-se quatro oficiais. Assim como outros que passaram pela chapelaria, esses últimos trabalhadores poderiam ter se qualificado em alguma outra empresa do ramo ou na própria Antônio José Maia \& Irmão, que, desde os anos 1870, produzia e consertava manualmente esse importante item do vestuário masculino e feminino.

O segundo grupo de operários contém seis $(17,14 \%)$ oficiais: dois apropriagistas, dois fulistas, um arcador e um tintureiro. Na época de sua contratação na fábrica a vapor de chapéus, todos tinham mais de 19 anos e ocupavam o lugar de aprendiz. ${ }^{86}$ Em outro momento do artigo, demonstramos que esse era um emprego precarizado para suas idades, fruto do processo de proletarização das oficinas. Apesar de serem alvos preferenciais da rotatividade da mão de obra, eles driblaram as estatísticas, mantiveram-se na linha de produção, acumularam alguma prática e subiram os primeiros degraus do aperfeiçoamento profissional. Os estudos históricos sobre as chapelarias portuguesas indicam que, antes da mecanização, o neófito aprimorava sua mão de obra com quatro ou cinco anos de tirocínio. ${ }^{87}$ Depois de introduzido o maquinário, dois anos era tempo suficiente para que o iniciante conquistasse as habilidades básicas de

86 Até aqui, tudo em: Maço “Impostos, Recife, 1886, Ant ${ }^{\circ}$ Je Maia \& Cia”, Petições Impostos 32.4 (1884-1889), APEJE, Recife-PE, Fundo: petições; natureza: manuscrito.

87 MÓNICA, op. cit., p. 942. 
um oficial, caso fosse acompanhado por um mestre. ${ }^{88}$ Comparado com os apropriagistas do primeiro grupo, o segundo contava com oficiais mais jovens (em 1886, sua faixa etária era 25,33 anos) e recém-promovidos. Nas rotinas fabris, do ponto de vista hierárquico, esses últimos estavam submetidos àqueles.

O terceiro grupo contém apenas um $(2,86 \%)$ oficial de apropriagem. Ele havia sido contratado com esse grau de especialização no primeiro semestre de 1882, quando possuía 18 anos. Para os critérios de escrituração de Antônio José Maia \& Cia., Antônio Augusto Collás era menor naquela oportunidade. Em 1886, considerado adulto, e com muita experiência em seu ofício, o nativo estava com 22. O histórico desse funcionário deveria ser parecido com o de seus colegas do primeiro grupo, que se aperfeiçoaram em outras chapelarias recifenses ou de alhures. Junto disso, algumas informações nos ajudam a compreender sua precocidade profissional. Ele era filho de Ezequiel Antônio Collás, que ainda empregou dois outros descendentes na fábrica a vapor de chapéus. No segundo semestre de 1884, Sótero Antônio e Victor Collás, com 35 e 34 anos respectivamente, também foram registrados como oficiais de apropriagem. Entretanto, eles perderam ou deixaram o emprego até o início de novembro de $1886 .{ }^{89}$ Bastante provável é que o patriarca da família fosse operário do ramo e seus filhos seguissem pelos mesmos caminhos. Historicamente, o sentido de "hereditariedade" era algo bastante comum nas profissões ditas mecânicas. ${ }^{90}$

Assim como o oficial de apropriagem Antônio Augusto Collás, os membros do quarto grupo também alcançaram a maioridade enquanto trabalhavam na fábrica a vapor de chapéus. A principal diferença é que todos os seus componentes haviam sido admitidos como menores aprendizes de Antônio José Maia \& Cia. O conjunto contabilizava 20 (57,14\%) meninos e rapazes contratados entre os anos de 1882 e 1884 . Um deles havia chegado às oficinas para aprender como se fazia a pesagem das matérias-primas. Os patrões e seus prepostos ensinaram-Ihe como conferir os insumos que chegavam ao almoxarifado. Mestres e oficiais, por sua vez, como medir a quantidade de pelos e de lãs necessárias aos processos fabris. Os outros foram assim divididos na linha de produção: cinco na apropriagem, dez na fula, três na arcagem e um na engomação. Até 6 de novembro de 1886, assim como seus colegas do segundo grupo, eles conseguiram escapar das engrenagens da rotatividade da mão de obra. Com isso, acumularam mais de dois anos de experiência em suas profissões e se tornaram oficiais recém-promovidos. Contudo, um pouco mais novos, computavam a faixa etária de 19,95 anos naquela última data.

No tocante aos dados familiares, dentre os 20 operários que alcançaram a maioridade e o oficialato, 13 (65\%) tinham o nome do pai nos livros de registro de Antônio José Maia \& Cia. A maior parte, 11, apresentava-se com o mesmo sobrenome daquele parente. Acompanhados do nome da mãe, contabilizamos três - 15\%. Quatro (20\%) tinham a filiação ignorada, sendo provavelmente órfãos ou enjeitados. Em vista disso, recordemos os números relativos aos 33 menores aprendizes contratados até 3 de julho de 1882, dia da inauguração oficial da fábrica a vapor de chapéus. Nessa data festiva, $60,61 \%$ dos meninos e rapazes possuíam o nome

88 CRUZ, op. cit., p. 86.

89 Até aqui, tudo em: Maço "Impostos, Recife, 1886, Ant ${ }^{\circ}$ Je Maia \& Cia", Petições Impostos 32.4 (1884-1889), APEJE, Recife-PE, Fundo: petições; natureza: manuscrito.

90 HOBSBAWM, Eric J. Mundos do trabalho: novos estudos sobre a história operária. Rio de Janeiro: Paz e Terra, 2000. p. 372. 
do pai registrado, sendo que a maioria, 17 de 20, surgiu com o mesmo sobrenome paterno. As mães de 15,15\% (5) foram reveladas nos papéis. Desconheciam suas origens parentais $21,21 \%-7$ funcionários. Um (3,03\%) surgiu sem dados. Ao compararmos as percentagens, reforçamos uma importante percepção, independentemente do número de sujeitos que estejam na interseção dos dois conjuntos. Na diacronia, os membros de famílias socialmente reconhecidas e chefiadas por homens continuavam com maiores níveis de empregabilidade.

Das duas dezenas de brasileiros que acabavam de entrar na vida adulta e no oficialato, quatro $(20 \%)$ haviam sido menores aprendizes protegidos pela Lei $n^{\circ} 1.289$. Em tese, eles gozaram dos cuidados oferecidos por Antônio José Maia \& Cia. Foram eles dois apropriagistas, um fulista e um engomador. Com a média de 20 anos em finais de 1886, três surgiram nas fontes com o nome do pai registrado (um com o sobrenome paterno) e outro com a filiação ignorada. ${ }^{91} \mathrm{O}$ direito conquistado, caso tenha sido efetivamente respeitado por patrões e seus prepostos, criou condições mais favoráveis (ou menos desfavoráveis) para que o quarteto conseguisse manter-se na fábrica a vapor de chapéus. Na seção anterior, indicamos que, quando da feitura do relatório destinado às autoridades fiscais pernambucanas, 11 meninos e rapazes, aprendizes internos, não estavam mais presentes na Rua do Visconde de Goiana. Sabemos agora que, desse total, quatro tornaram-se adultos e foram promovidos nas hierarquias fabris. Em outras palavras, deixaram de ser objeto daquela norma, abrindo novas vagas para quem quisesse aprender um ofício com mais segurança material - ou menos insegurança material.

Do conjunto dos 35 trabalhadores brasileiros (homens adultos mais ou menos qualificados em seus ofícios, empregados até o dia 6 de novembro de 1886), 13 trabalhavam desde o primeiro semestre de 1882 e estiveram na inauguração da fábrica a vapor de chapéus. Considerando-se os mais adestrados do ponto de vista profissional e amadurecidos pelo tempo de vida, arrolamos um maquinista que operava o "moderno" motor portuense e dois oficiais de apropriagem. Nesse último ofício, com a mesma graduação e semelhante experiência, porém mais jovem, temos Antônio Augusto Collás. O quinto operário também era oficial de apropriagem, mas estava entre os adultos que foram admitidos como aprendizes. Engrossando o número de colegas na referida oficina, mais três oficiais haviam sido menores aprendizes. Dois usufruíram das benesses da Lei no 1.289 . Também contratados na mocidade e burilados pelo duro tirocínio da chapelaria de Antônio José Maia \& Cia., somam-se mais quatro oficiais de fula (um deles fora menor aprendiz interno, enquanto pôde gozar do direito provincial) e um de arcador. Juntos com os dois mestres portugueses, portanto, sabemos até agora que 15 veteranos ainda continuavam na Rua do Visconde de Goiana, n. 147.

O $36^{\circ}$ brasileiro maior, que fecha a respectiva listagem, era aprendiz de apropriagem. Domingos Jacob Oliveira foi admitido em 11 de junho de 1885, quando tinha 18 anos. Assim como no caso de Antônio Augusto Collás, os critérios de escrituração de Antônio José Maia \& Cia. enquadraram aquele neófito como menor, quando de sua admissão. Em 6 de novembro de 1886, com 19, o filho legítimo de Joaquim Rodrigues Oliveira acumulava quase um ano e meio de tirocínio na fábrica a vapor de chapéus. ${ }^{92}$ Com um pouco mais de tempo nas duras

91 Até aqui, tudo em: Maço "Impostos, Recife, 1886, Ant ${ }^{\circ} J^{e}$ Maia \& Cia”, Petições Impostos 32.4 (1884-1889), APEJE, Recife-PE, Fundo: petições; natureza: manuscrito.

92 Até aqui, tudo em: Maço “Impostos, Recife, 1886, Ant ${ }^{\circ} J^{\text {J }}$ Maia \& Cia”, Petições Impostos 32.4 (1884-1889), 
rotinas da apropriagem, o trabalhador passaria para outro nível de perícia em sua profissão. Segundo a historiografia sobre os chapeleiros portugueses, como indicamos, em alguns meses o nativo seria reconhecido como oficial em início de carreira. Talvez, esperançoso com seu futuro imediato, Domingos Jacob Oliveira se espelhasse no exemplo de cinco colegas lotados em sua oficina. E se olhasse para os lados, poderia mirar outros 14 operários com histórias semelhantes à sua nos serviços de fula, arcagem e engomação. Como analisamos mais acima, contidos no grupo quatro, eles eram jovens adultos recém-graduados ao oficialato e ex-menores aprendizes.

Antônio José Maia \& Cia. também contava com 25 brasileiras maiores de 19 anos em sua linha de montagem $-23,81 \%$ da força de trabalho existente na fábrica a vapor de chapéus. Desse montante, 12 (48\%) haviam sido contratadas como aprendizes entre o segundo semestre de 1882 (depois da inauguração oficial, ocorrida em 3 de julho) e 1884. Assim como alguns de seus colegas homens, essa dúzia de operárias escapou das sombras da rotatividade no período de instrução e, com o tempo, alcançou melhor nível de aperfeiçoamento profissional. Dessa forma, em finais de 1886, com a média de 33,75 anos, nove costureiras e três afinadeiras mais bem qualificadas formaram-se nas oficinas da chapelaria. As outras 13 (52\%), em sua maior parte contratada no transcorrer daquele último ano, seguiram a tendência histórica de serem adultas admitidas como aprendizes de costureira. Mais jovens (faixa etária de 27,61 anos) que as componentes do primeiro grupo e sem a necessária experiência para confeccionar forros e ornamentos bem-acabados, sua continuidade na Rua do Visconde de Goiana era extremamente ameaçada pelas conjunturas, assim como demonstramos em outra seção do artigo.

Trabalhando ao lado das 13 costureiras adultas e aprendizes, sete meninas e moças (6,7\% da mão de obra presente) também davam os primeiros passos no ofício. Todas foram contratadas em 1886, com a média de 15,86 anos. No tocante às suas famílias, quatro tinham o nome da mãe registrado, uma o do pai e duas não possuíam dados anotados. Os meninos e rapazes aprendizes eram $19-18,1 \%$ dos empregados. Desses, $13(68,42 \%)$ foram admitidos em 1886 e seis $(31,58 \%)$ no ano anterior. Com a média de 16,05 anos, um raro estava na costura, 14 na apropriagem, dois na engomação, um na tinturaria e um na fula. Talvez, na fonte, assim como apontamos em outro caso, haja algum equívoco sobre a profissão do primeiro. No quesito filiação, o nome do pai acompanhava 12 operários, o da mãe seis e um ignorava seu parentesco. Os pequenos quantitativos nos impedem de encontrar um padrão mais detalhado, exceto pelo fato de que, como analisamos oportunamente, os menores e as menores com parentela declarada tinham mais chances de arrumar serviços. Ao mesmo tempo, de forma dramática, quase todo esse pessoal teria como destino o desemprego, após responderem essa ou aquela demanda.

O último grupo, que encerra o arrolamento dos 105 operários e operárias da fábrica a vapor de chapéus, é composto por 14 rapazes que eram oficiais. O conjunto dos menores mais ou menos qualificados representava $13,33 \%$ da força de trabalho empregada pelos três portugueses. Assim como seu colega Antônio Augusto Collás, eles conquistaram esse nível de especialização antes da maioridade. Contudo, diferente daquele primeiro, o aperfeiçoamento

APEJE, Recife-PE, Fundo: petições; natureza: manuscrito. 
desses últimos foi alcançado nas próprias oficinas de Antônio José Maia \& Cia. Em 1882, dois iniciaram seu tirocínio na apropriagem e dois na engomação, quando apresentavam a média de 13,25 anos. Em 1886, com 17,25, estavam graduados há dois anos. Por sua vez, no ano de 1883, com a faixa etária de 14,33 , dois começaram sua aprendizagem na fula e um na apropriagem. No período da feitura do relatório apresentado às autoridades fiscais pernambucanas, com 17,33, os três operários haviam se graduado há um ano. Por último, em 1884, quatro deram seus primeiros passos na oficina de fula, dois na de cartonagem e um na de apropriagem. Naquela oportunidade, contabilizavam a média de 15,14. Dois anos depois, recém-promovidos ao oficialato, os sete alcançaram 17,14 .

O padrão familiar dos 14 menores que, em finais de 1886, estavam mais ou menos especializados em suas profissões, segue algumas tendências apontadas neste artigo. Sete (50\%) tinham o nome do pai registrado nas fontes, sendo que seis, absoluta maioria, possuíam o mesmo sobrenome paterno. O nome da mãe seguiu junto da inscrição de três $(21,43 \%)$ operários. Sem dados sobre sua filiação, encontramos três rapazes $-21,43 \%$. Apenas um $(7,14 \%)$ tinha pai e mãe ignorados. Aquela meia dúzia de pernambucanos, que carregava a alcunha de seus ascendentes masculinos, permite que façamos ilações semelhantes às que foram feitas sobre Antônio Augusto Collás, apropriagista brasileiro que alcançou o oficialato antes de completar 19 anos. Eles poderiam ser filhos legítimos de algum trabalhador do ramo da chapelaria, o que, além de garantir uma rede familiar mais sólida e protetiva, teria possibilitado um processo de aprendizagem precoce e com certo grau de acompanhamento externo. Em boa medida, essas formas de apoio poderiam minimizar abusos, promover respeitabilidade e prevenir excessivos maus-tratos nas oficinas da fábrica a vapor de chapéus de Antônio José Maia \& Cia.

Ainda atentos aos 14 rapazes pernambucanos que conquistaram maior ou menor lastro em seu novo nível técnico, dois apropriagistas e dois engomadores desfrutaram, no período de aprendizagem, dos benefícios previstos pela Lei $n^{\circ} 1.289 .{ }^{93}$ Esse quarteto foi aquele contratado em 1882, com média etária de pouco mais de 13 anos. A última dupla de profissionais foi admitida depois da inauguração oficial da fábrica a vapor de chapéus. $A$ primeira foi empregada antes e participou dos festejos do dia 3 de julho. Portanto, desde essa data até 6 de novembro de 1886, existiram 17 veteranos na linha de produção. Junto dos dois jovens oficiais de apropriagem, recordemos, estiveram 13 compatriotas e dois portugueses. Levando-se em consideração que havia 105 operários e operárias quando da feitura do relatório destinado às autoridades públicas, preservou-se, em quase cinco anos de operação, apenas $16,2 \%$ da força de trabalho primordialmente instalada na Rua do Visconde de Goiana, n. 147. Não nos escapa o fato de toda ela ser masculina e a maior parte possuir mais de 19 anos, o que reforça a percepção de que meninos, rapazes, meninas, moças e mulheres adultas eram os alvos preferencias da rotatividade da mão de obra.

Tendo em vista as análises feitas até aqui, baseadas nos dados do relatório produzido em 6 de novembro de 1886, podemos relativizar a informação de que existiam, naquela data, quatro menores aprendizes internos na fábrica a vapor de chapéus. Segundo os registros, de certa forma distorcidos pela firma, seriam eles os dois apropriagistas e os dois engomadores

93 Até aqui, tudo em: Maço "Impostos, Recife, 1886, Ant ${ }^{\circ} J^{\mathrm{e}}$ Maia \& Cia”, Petições Impostos 32.4 (1884-1889), APEJE, Recife-PE, Fundo: petições; natureza: manuscrito. 
que, mesmo sendo menores de 19 anos, conquistaram o status de jovens oficiais em passado recente. Parece óbvio que, na diacronia, todos deixaram de ser objeto da Lei $n^{\circ} 1.289$, que somente deveria proteger meninos e rapazes aprendizes. Assim sendo, todos os membros daquele quarteto não mais apresentavam condições para receber comedorias, roupas e medicamentos. Nesse sentido, diferentemente do que declarava o documento produzido por Antônio José Maia \& Cia., ninguém mais desfrutava daquele apoio legal na Rua do Visconde de Goiana, n. 147. Contudo, sabemos que o estabelecimento fabril contava com a mão de obra de 19 garotos e de sete garotas, iniciantes em suas possíveis novas profissões. Para os empresários, preocupados com o lucro, não valia a pena investir na formação de gente que seria descartada em poucos meses ou semanas.

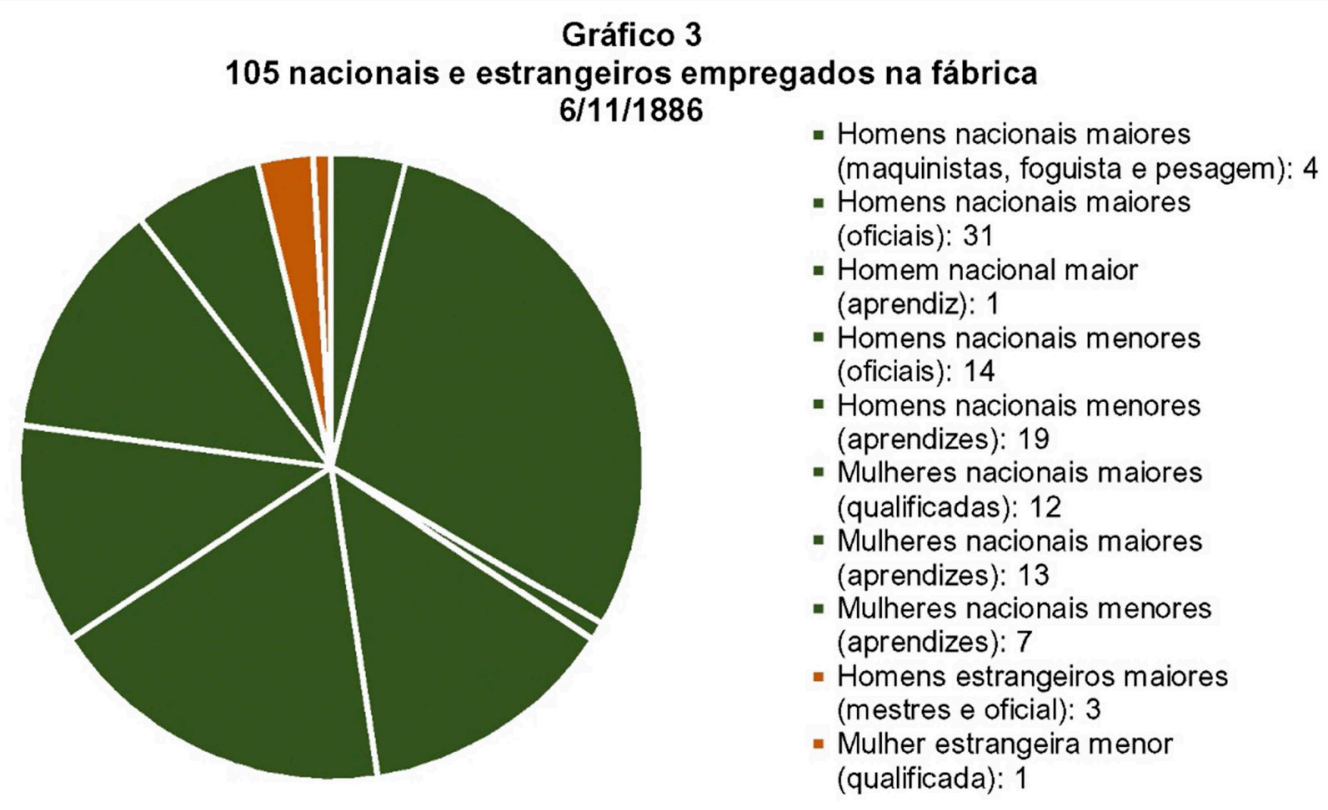

Fonte: Maço “Impostos, Recife, 1886, Ant ${ }^{0}$ Je Maia \& Cia.", Petições Impostos 32.4 (1884-1889), Arquivo Público Estadual Jordão Emerenciano (Recife-PE), Fundo: petições; natureza: manuscrito.

\section{Considerações finais}

OS DADOS DOS GRÁFICOS 1, 2 e 3, relacionados às análises feitas no transcorrer do artigo, permitem algumas conclusões importantes. Ao compararmos os quadros operacionais da fábrica a vapor de chapéus, observamos que houve um aumento quantitativo do pessoal qualificado. No dia da abertura de suas portas para as autoridades provinciais e para o grande público, mestres, oficiais e mão de obra especializada em geral somavam $42,5 \%$. $\mathrm{Na}$ época da feitura do relatório entregue às autoridades fiscais pernambucanas, $61,9 \%$. Apesar do aumento em termos absolutos, devemos ter cuidado com seus significados. Entre os dois marcos temporais, quase todos os experientes profissionais portugueses e brasileiros deixaram ou foram demitidos da linha de produção. Saíram 23 oficiais: 14 fulistas, um arcador, um carpina, um cartoneiro e seis apropriagistas. Por sua vez, nenhuma especialista portuguesa se manteve. Duas costureiras, duas afinadeiras e uma sem profissão registrada também deixaram a firma de Antônio José Maia \& Cia. Caso os estrangeiros e as estrangeiras 
tivessem vindo do Porto sob contrato de locação de serviços, poderiam tê-lo descumprido pelos mais diferentes motivos ou seguiram seus destinos após o acordo expirar.

Para ocupar o lugar dos oficiais experientes e das portuguesas qualificadas, os patrões promoveram os brasileiros que se especializaram na própria fábrica a vapor de chapéus. Dentre os 17 veteranos presentes desde o primeiro semestre de 1882, um ex-aprendiz adulto se tornou oficial de apropriagem, oito ex-aprendizes menores chegaram à maioridade e ao oficialato exercendo diversas profissões e dois ex-aprendizes menores se tornaram oficiais de apropriagem antes dos 19 anos. No conjunto da mão de obra sem experiência prévia, presente desde o período compreendido entre o segundo semestre de 1882 e finais de 1884, 29 pernambucanos das mais diferentes idades alcançaram o oficialato e substituíram os ex-funcionários. Em mesmo interregno, as costureiras e as afinadeiras portuguesas foram trocadas por 12 brasileiras adultas que alcançaram suficiente nível técnico após uma temporada de aprendizagem. Outra prova da opção pelos nacionais formados nas oficinas da chapelaria foi o recrutamento de apenas oito lusitanos depois de 3 de julho de 1882. Desses, em finais de 1886, restou um oficial de fula e uma jovem costureira. Somente três oficiais brasileiros foram contratados após a inauguração, mas nenhum ficou.

No bojo da política de promoção dos ex-aprendizes, com seu reaproveitamento em níveis mais especializados, chama a atenção o fato de inexistirem menores aprendizes internos no final de 1886. A Lei $\mathrm{n}^{\circ} 1.289$ ainda vigorava e estava sendo desrespeitada por Antônio José Maia \& Cia. No documento enviado às autoridades fiscais pernambucanas, os três proprietários portugueses assim justificaram o descumprimento da norma: certa negligência da força policial, que não remetia meninos e rapazes para seu estabelecimento fabril, e dos "pais, tutores e mais pessoas encarregadas desses menores, que não gostam de os sujeitar a contrato". Preocupados com a continuidade de suas isenções fiscais, os relatores ainda tentavam sensibilizar o poder público com o argumento de que sempre mantiveram aprendizes em número superior ao exigido, o que lhes permitiu formar mais de 30 oficiais que "vão buscar o pão cotidiano" na Rua do Visconde de Goiana, n. 147. ${ }^{94}$ Como averiguamos nas fontes, há certa verdade nessas últimas palavras, mas notamos uma manipulação dos fatos quanto aos menores aprendizes internos, que somente extrapolaram o total de uma dúzia no início das operações da fábrica a vapor de chapéus.

Todas essas estratégias foram muito bem arquitetadas para que Antônio José Maia \& Cia. pudesse minimizar custos e maximizar lucros. Para tanto, dispensou mão de obra local e estrangeira experiente, promoveu um oficialato nativo, mais jovem e recém-graduado e burlou a obrigação legal de oferecer auxílios para 12 menores aprendizes internos. Não bastasse isso, também explorou centenas de meninos, rapazes e mulheres adultas que, admitidos como "aprendizes", somente realizaram serviços por demanda, de caráter pontual e temporário. Os indícios apontam para o sucesso financeiro dessas medidas. Em seus primeiros momentos, como sabemos, o valor da fábrica a vapor de chapéus era de 50:000\$000 Rs. Um balanço fechado em 31 de dezembro de 1886 determinou que seu capital era de 115:731\$630 Rs. ${ }^{95} \mathrm{Em}$

94 Até aqui, tudo em: Maço “Impostos, Recife, 1886, Ant ${ }^{\circ} J^{\text {J }}$ Maia \& Cia”, Petições Impostos 32.4 (1884-1889), APEJE, Recife-PE, Fundo: petições; natureza: manuscrito.

95 Contrato n. 101, Sociedades commerciais registradas no ano de 1887, Secretaria da Junta Commercial da Cidade do Recife, JUCEPE, Fundo: Junta Comercial de Pernambuco; natureza: manuscrito. 
quase cinco anos, portanto, registrou-se um salto de 131,46\%. Apesar de as autoridades fiscais pedirem satisfações sobre o desrespeito à Lei no 1.289 , parece que nenhuma sanção foi imposta aos empresários. Ao contrário, em 1889, com um novo sócio português, a rebatizada Alves, Maia \& Cia. recebeu um novo aporte de recursos e seu capital passou para 158:916\$160 Rs. ${ }^{96}$

Um motivo que talvez tenha impedido sanções governamentais à fábrica a vapor de chapéus foi o grande número de trabalhadores nacionais admitidos e em atividade. Por causa disso, o tesouro provincial pode ter sido obrigado a passar panos quentes no desrespeito à Lei $n^{\circ} 1.289$. Até mesmo porque, como afirmaram os três proprietários portugueses, no relatório produzido em finais de 1886, ao sofrer "grandes prejuízos" precisariam lançar "à rua mais de cem famílias que nessa casa de trabalho honesto vão buscar o pão cotidiano". ${ }^{97}$ Essa questão da sobrevivência da classe operária foi reiterada no documento algumas vezes, pois era muito sensível o problema do desemprego em uma economia em crise. Acuados pelo discurso patronal, os homens públicos acabaram trocando um mal maior por outro menor. Não era possível penalizar a empresa, pois, mesmo que não mais existissem menores aprendizes internos na Rua do Visconde de Goiana, o endereço abrigava 40 neófitos e 61 oficiais brasileiros dos mais variados gêneros, idades e níveis de especialização. Portanto, ao se apropriar com inteligência das demandas históricas pelo emprego da mão de obra local, os sócios conseguiram dividendos financeiros e simbólicos.

Em 1890, no alvorecer do período republicano, as duras experiências dos operários e das operárias da firma de Antônio José Maia \& Cia. ajudaram a alicerçar as lutas da recém-criada Liga Operária de Pernambuco. Entre outras pautas, o grupo defendia a conquista de direitos para crianças e mulheres trabalhadoras, que, historicamente, sempre foram os proletários mais precarizados. Por causa disso, o Partido Operário de Pernambuco, seu braço eleitoral, reforçou, no pleito de 1891, a necessidade de se reformar o trabalho infantil e feminino. ${ }^{98}$ Essa era uma luta nacional, que viabilizou, em mesmo ano, a aprovação do Decreto $\mathrm{n}^{\circ} 1.313$, que regulamentava o trabalho de menores nas indústrias. ${ }^{99}$ Ainda em 1891, no bojo desse processo, segundo Felipe Souza, a briga por melhores salários deflagrou uma greve na Cia. Indústria de Chapéus. ${ }^{100}$ Ao consultarmos os jornais recifenses, o estabelecimento estava na Rua do Visconde de Goiana, n. 147. ${ }^{101}$ Possivelmente, aquele fosse o nome fantasia de Alves, Maia \& Cia. O negócio havia mudado de nome, mas não suas práticas. Contudo, outras histórias começavam a ser escritas pela gente que, nas oficinas e nas ruas recifenses, deixava de tirar seu chapéu em reverência aos patrões.

Recebido em 07/11/2019

Aprovado em 21/12/2019

96 Contrato n. 53, Sociedade commerciais registradas no ano de 1889, Secretaria da Junta Commercial da Cidade do Recife, JUCEPE, Fundo: Junta Comercial de Pernambuco; natureza: manuscrito.

97 Maço "Impostos, Recife, 1886, Ant ${ }^{\circ} \mathrm{Je}^{\mathrm{M}}$ Maia \& Cia", Petições Impostos 32.4 (1884-1889), APEJE, Recife-PE, Fundo: petições; natureza: manuscrito.

98 MAC CORD, Marcelo. Direitos trabalhistas em construção: as lutas pela jornada de oito horas em Pernambuco, 1890-1891. Tempo, Niterói, v. 22, n. 39, p. 181 e 190, jan.-abr. 2016.

99 MORAES, op. cit., p. 31.

100 SOUZA, op. cit., p. 213.

101 Jornal do Recife, Recife, 21 mai. 1891. Disponível em: http://memoria.bn.br/hdb/periodico.aspx. Acesso em: 20 set. 2019. 